


\section{RUSSIAN ACADEMY OF SCIENCES \\ INSTITUTE FOR THE HISTORY OF MATERIAL CULTURE}

\section{B ULLETIN}

№ 10

RESCUE ARCHAEOLOGY

ST. PETERSBURG

2020 


\section{РОССИЙСКАЯ АКАДЕМИЯ НАУК \\ ИНСТИТУТ ИСТОРИИ МАТЕРИАЛЬНОЙ КУЛЬТУРЫ}

\section{БЮЛЛЕТЕНЬ}

№ 10

ОХРАННАЯ АРХЕОЛОГИЯ

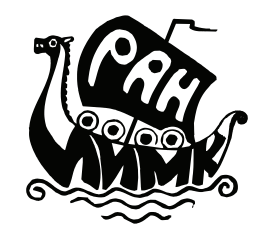

САНКТ-ПЕТЕРБУРГ

2020 
УДК 902/904

ББК 63.4

Б98

Рецензенты:

В.А. Лапшин (директор ИИМК РАН)

И. Л. Тихонов (Институт истории СПбГУ)

Ответственный редактор Н.Ф. Соловьёва

Технический редактор, оформитель С. Л. Соловьёв

Перевод: А.В. Гилевич

Корректор: А.О. Поликарпова

Бюллетень Института истории материальной культуры Российской академии наук: (охранная археология). [№] 10 / науч. ред. Н.Ф. Соловьёва;

ИИМК РАН. - СПб.: Изд-во ООО «Невская Типография», 2020. - 193 с. : ил.

Bulletin of the Institute for the History of Material Culture Russian Academy of Sciences:

(rescue archaeology). [№] 10 / ed. by N.F. Solovyova;

IHMC RAS. - SPb.: Publishing House LLC «Nevsky Printing House», 2020. - 193 pp. : ill.

ISBN 978-5-907298-13-2

Периодическое издание посвящено охранно-археологической деятельности ИИМК РАН по изучению культурного наследия России. Десятый номер бюллетеня представляет результаты археологических исследований объектов культурного наследия Санкт-Петербурга и его окрестностей, а также других регионов России, которые были осуществлены Отделом охранной археологии ИИМК РАН в сотрудничестве с другими научными, образовательными и государственными организациями в 2017-2020 гг.

Издание предназначено для историков, археологов, государственных служащих, частных предпринимателей и широкого круга читателей, заинтересованных в научной и достоверной информации об истории России и состоянии памятников ее культуры.

This periodical is dedicated to the rescuing and archaeological activities of the Institute for the History of Material Culture (IHMC) RAS in studies of the cultural heritage of Russia. The tenth issue of the Bulletin presents the results of archaeological investigations of the cultural heritage of St. Petersburg and its surroundings, as well as other regions of Russian Federation, carried out in 2017-2020 by the Department for Rescue Archaeology of IHMC RAS in collaboration with other scientific, educational and public organizations.

This publication is intended for historians, archaeologists, government employees, private entrepreneurs and a wide circle of readers interested in reliable scientific information on history of Russia and the state of the monuments of its culture.

ISBN 978-5-907298-13-2

УДК 902/904

ББК 63.4

(С) ИИМК РАН, Санкт-Петербург, 2020

(c) Отдел охранной археологии ИИМК РАН, 2020 


\title{
Исследования ржевского городища Соборная Гора ${ }^{1}$
}

\author{
К.А. Михайлов ${ }^{2}$, К.В. Горлов ${ }^{3}$
}

DOI: $10.31600 / 978-5-907298-13-2-2020-140-163$

Традиционно считается, что первое упоминание о средневековом Ржеве содержится в летописях под 1216 г. Он был упомянут в связи с одним из эпизодов войны торопецко-новгородского князя Мстислава Мстиславовича Удатного с сыновьями великого князя владимирского Всеволода Большое Гнездо. Отряд князя Святослава Всеволодовича осадил город, но был отбит ржевским гарнизоном во главе с воеводой Якуном и новгородскими войсками под командованием Мстислава Удатного. По мнению ряда исследователей, Ржев, или Ржева Володимерова, могла существовать уже во второй половине XII в., хотя письменные источники таких сведений не содержат. Вероятно, город был основан в конце XII - начале XIII в. братом князя Мстислава Удатного князем Владимиром Мстиславовичем. На это указывает дополнительное наименование города (Ржева Володимирова), бытовавшее до начала XIX в, а также местное почитание мощей этого князя и его супруги Агриппины, находившихся в главном храме города - Успенском соборе до середины XVIII в. (Нефёдов, 2007. С. 232).

В XIII-XIV вв. город формально входил в состав Смоленской земли, а в первой половине XIII в. принадлежал Торопецкому удельному княжеству. История Ржева в середине XIII - первой половине XIV в. не вполне ясна. Он редко упоминается в письменных источниках. Вероятно, во второй половине-конце XIII в. город стал центром удельного княжества. Под 1314 г. в летописи упоминается князь Фёдор Ржевский, находившийся

\footnotetext{
${ }^{1}$ Работа выполнена в рамках программы ФНИ ГАМ по теме государственного задания № 0184-2019-0006. «Ремесло, торговля, международные связи Северной Руси и её соседей». 2 191186, Санкт-Петербург, Дворцовая наб. 18. Институт истории материальной культуры РАН. Отдел славянофинской археологии. E-mail: mikhailov_kirill@mail.ru.

${ }^{3}$ Россия, 191186, Санкт-Петербург, Дворцовая наб., 18. Институт истории материальной культуры РАН, Лаборатория камеральной и цифровой обработки, учета и хранения археологических коллекций. E-mail: costik.gorlov@yandex.ru.
}

на службе у московского князя Юрия Даниловича. С этого момента почти на два столетия пограничный Ржев становится ареной ожесточенной борьбы между литовскими, московскими и тверскими князьями.

В 1356 г. Ржева Володимирова была захвачена литовскими войсками, после чего Ольгердом в ней был посажен Иван, сын сижского удельного князя, но в следующем году ее отбила волоцкая и можайская рати. В 1359 г. Андрей Ольгердович опять подчиняет Ржеву Литве. Считается, что именно в этот момент она окончательно перестала входить в Смоленское княжество, но, по мнению В.Л. Янина, Литва захватила город еще раньше в первой четверти XIV в. (Нефёдов, 2007. С. 233).

Во второй половине XIV - первой половине $\mathrm{XV}$ в. Ржев, занимая стратегическое положение на границе Литовского, Московского и Тверского княжеств, оставался объектом борьбы между ними и неоднократно переходил из рук в руки. В 1358-1372 гг. город несколько раз попеременно захватывался Москвой и Литвой. Например, в 1368 г. Ржевская «земля» была завоевана войсками московского княжества под командованием князя Владимира Андреевича Серпуховского (Храброго). До 1372 г. город и княжество принадлежали Москве, но в 1376 г они опять были присоединены к Великому княжеству Литовскому. В списке русских городов «дальних и ближних» 1375-1381 гг. Ржев назван в числе прочих литовских владений. Более или менее прочно город вошел в состав Великого княжества Московского только в 1381 или 1382 г. В результате в 1386 г. ржевская рать идет на Новгород вместе с московскими полками. Во время междоусобицы в Московском княжестве Ржев ненадолго захватил племянник князя Василия Темного Василий Юрьевич Косой, а затем он был передан его брату Дмитрию Юрьевичу Шемяке.

В 1399 г. Ржева, по предположению В.А. Кучкина, была уступлена Москвой Твери в обмен на отказ от союза с Литвой, но около 1404 г. она вер- 
нулась в состав Московского княжества. В 1408 г. по велению великого князя Московского воеводы Юрий Козельский и Юрий Васильевич ржевскую крепость срубили заново. В том же году великий князь Василий I пожаловал Ржев в кормление литовскому князю Свидригайло Ольгердовичу. В 1446 г. князь Василий II вновь уступает Ржев великому тверскому князю Борису Александровичу. В том же году тверской князь осаждал Ржев с применением артиллерии и взял его (Квашнин-Самарин, 1887. С. 35; Кучкин, 1984; Воротникова, Неделин, 2013. С. 712, 713; Исланова, Оруджев, 2017. С. 91). Но, уже в 14481449 гг. Ржев был вновь захвачен войсками польского короля и великого князя литовского Казимира IV Ягеллончика. Окончательно Ржев закреплялся за Москвой по русско-литовскому договору 1449 г. Современник этих событий в «Инока Фомы Слово похвальное» дал такую характеристику Ржеву: «... радок той аще ли мал, но твердъ, и велми приправы градскые на нем велми много».

Предполагается, что в первой половине XV в. детинец города имел мощные деревянные укрепления, построенные московскими князьями в 1408 г., и, предположительно, был оснащен артиллерией. Во второй половине $\mathrm{XV}$ в. Ржев становится московским уездным городом, и в 1462 г. великий князь Василий II Темный завещал его своему младшему сыну Борису Волоцкому, который в 1494 г. разделил город и его уезд по р. Волге между своими сыновьями Фёдором Волоцким (левобережье) и Иваном Рузским (правобережье). После смерти князя Ивана Борисовича Рузского в 1503 г. принадлежавшая ему половина Ржева перешла к князю Дмитрию Углицкому, сыну Ивана III. После смерти князя Фёдора Борисовича Волоцкого в 1513 г. и князя Дмитрия Ивановича в 1521 г. обе части города управлялись московскими наместниками. В конце Ливонской войны в 1581 г. польско-литовская армия под командованием напольного гетмана князя Христофора Радзивилла сожгла городской посад, но не смогла взять крепость (Нефёдов, 2007. С. 232, 233).

В XVI в. Ржев служил сборным пунктом московских войск для походов на Великое княжество Литовское и Ливонию. Во время восстания Ивана Болотникова Ржев осенью 1606 г. заняли повстанцы, но вскоре город был «очищен» от болотниковцев смоленской ратью. В 1608 г. Ржев перешел на сторону Лжедмитрия II. В январе 1610 г. русско-шведский отряд воеводы Ивана Андреевича Хованского и генерала Эверта Горна выбил из Ржева и Старицы сторонников самозванца и вернул их под власть царя Василия Шуйского. Уже в марте 1610 г. город захватили войска польского короля
Сигизмунда III Васы, но вскоре он был отбит московскими войсками.

В 1615 г. Ржев стал центром сбора отрядов во главе c боярином Федором Ивановичем Шереметевым, которые должны были отправиться на помощь осажденному шведами Пскову, но осенью 1615 г. Ржев стал одной из жертв стремительного рейда литовского полковника Александра Лисовского. Внезапным нападением лисовчики смяли полк Шереметева, захватил его обозы и загнали остатки московских ратников в крепость. Летописец так описывал эти события: «На ратных людей на коши под Ржавой на походе пан Лисовской с польскими и литовскими людми пришел и с рускими с воры и с изменники... и много туто ратных людей кошевых побили, и коши поимали» (ПСРЛ. Т. 34. С. 263). Московские служилые люди были застигнуты врасплох «на посаде и по слободам». Разгром был полным. Воевода Ф. И. Шереметев с остатками своей рати заперся в Ржевском остроге, а Лисовский «к городу приступал великими приступы» (ПСРЛ. Т. 14. С. 137). Затем полковник стал лагерем на противоположном берегу Волги. Хотя посад и был разорен, сам «город» (т. е. крепость на Соборной Горе) противнику взять не удалось. В боях погибло немало лисовчиков и, согласно легенде, раздраженный неудачей, Лисовский приказал снять колокола с пригородных церквей и бросить их в колодцы. Затем он снял осаду и ушел к Кашину и Угличу (Зорин, 2009. С. 224-231; Воротникова, Неделин, 2013. С. 713, 714).

Бурные события XVII в. заставляли московские власти регулярно перестраивать ржевские укрепления. До 1630 г. Ржевская крепость представляла собой деревянный острог с протяженностью стен в 276 сажен (около 588 м), с тремя воротами и пятью глухими башнями. В конце 1630 г. на соседней с Соборной, Каргошиной горе построили второй острог, который защищал городской посад. В результате перестроек укрепления на стрелке мыса получили название Старого или Верхнего города (ныне Соборная Гора), а примыкавшие к ним с запада укрепления посада - Новоприбавочного города. В результате перестроек в Старом городе (ржевском кремле) появилось 11 башен. Внутри крепости на горе находились деревянный Успенский собор, церковь Св. Параскевы Пятницы, воеводский двор, осадные дворы горожан и другие постройки (Воротникова, Неделин, 2013. С. 714).

В 1650-х гг. Ржев, сохраняя свое важное военностратегическое значение на московско-литовском пограничье, имел крупный гарнизон и являлся местом сбора русских войск во время войн с Речью Посполитой. Его укрепления неоднократно перестраивались 
и расширялись. В публикации члена Тверской ученой комиссии священника В.П. Успенского в связи с историей Рожковского погоста Осташковского уезда упоминается о нескольких перестройках ржевской деревянной крепости в течении XVII в. Например, в 1654 г. при ржевском воеводе Андрее Вельяминове «в старом городе на старой осыпи (на прежнем валу) построили крепостную башню; в 1669 г. в Ржеве происходила перестройка «всей крепости, и главной, и новодобавочной»; в 1673 г. строительство и обновления в крепости продолжались. Крепостными работами руководил Иван Григорьевич Мусин-Пушкин ${ }^{4}$. После окончания тринадцатилетней войны с Польшей в 1667 г. Ржев потерял свое военное значение и обновления городских укреплений прекратились (Нефёдов, 2007. С. 232, 233).

По-видимому, ветхие деревянные стены и башни Ржевской крепости продолжали стоять на городище до 1730-х гг. Так, по описанию И.К. Кириллова (1727 г.), в Ржеве значится: «Город деревянной, рубленой, в него 2 башни презжих, 8 глухих...» (Воротникова, Неделин, 2013. С. 715). Можно предположить, что окончательно деревянные стены деревянной крепости разобрали во время строительства каменного Успенского собора.

Первые описания городища (кремля, детинца) и сведения о средневековой истории Ржева приводятся Н.Д. Квашниным-Самариным (1887. C. 16, 17), но впервые систематизированные сведения об археологических памятниках и находках из Ржева и ржевского уезда были собраны В.А. Плетневым (1903. С. 65-70). В его работе в том числе приводятся сведения о находках каменного века с территории города, которые собирал член Тверской архивной комиссии П. Ф. Симсон. Значительную часть орудий, которые относятся к эпохи позднего палеолита-неолита, исследователь обнаружил около восточного края городища, в устье р. Хвалынки и к востоку от нее, в урочище Орешник (Симсон, 1903. С. 10-12). Ценные сведения об укреплениях ржевской крепости содержатся в работе ржевского историка и археолога П.Ф. Симсона. Исследователь смог выкупить часть бумаг ржевской приказной избы, в которых нашел список воевод, городовых приказчиков и описания городских укреплений в XVII в. (Симсон, 1916)5.

\footnotetext{
${ }^{4}$ Сведения получены из Книги городового дела г. Ржева [Володимирова] [горододельца] Ивана Григорьевича Мусина-Пушкина за 1670 г., которая хранится в Российской государственной библиотеке (РГБ).

5 К сожалению, архив П.Ф. Симсона погиб во время Великой Отечественной войны, а экземпляр монографии отсутствует в большинстве библиотек.
}

Археологические памятники Ржева попали во внимание исследователей в послевоенный период. В 1947 г. городище на Соборной Горе было осмотрено сотрудником ИИМК АН СССР Э.А. Рикманом. Он отметил, что видимых признаков вала на городище не сохранилось. Им же была произведена фотофиксация памятника (Рикман, 1951. С. 72). В 1958 г. при подготовке новой экспозиции Ржевского краеведческого музея городище обследовалось Ф.И. Ивановым. Совместно с геодезистом О.А. Кочкиным им был снят инструментальный план, произведена реконструкция системы оборонительных сооружений (Иванов, 1958). В 1972 г. городище обследовал Л. В. Алексеев, который снял глазомерный план городища Соборная Гора. Им же была собрана коллекция керамики, которую он отнес к XII-XIII вв. (Алексеев, 1972; 1980. С. 185). В 1979 г. после обследования городища Историко-археологической экспедицией Калининского (ныне Тверского) государственного университета П.Д. Малыгиным составлена учетная документация и утвержден паспорт на этот объект, в котором были закреплены хронологические рамки существования крепости - XIII-XVII вв. (Исланова, Оруджев, 2017. C. 91).

В 2004-2005 гг. разведочное обследование городища проводил Р.А. Оруджев. В результате был собран керамический материал на обнажениях, на окольном городе и внизу (к востоку от площадки) на огородах - на посаде городища (Оруджев, 2004; 2005). В 2010 г. экспедиция под руководством И.В. Ислановой производила обследование и шурфовку памятника (Исланова, 2010; Исланова, Оруджев, 2017. С. 92). Единственный шурф $(1,8 \times 1$ м) был заложен на восточном краю нижней площадки городища. Шурф был прокопан до материка, до глубины 1,4 м. Отчет 2010 г. стал единственным наблюдением за стратиграфией городища. В 2016 г. охранные работы на верхней площадке Соборной Горы проводились О.А. Козловой по договору с ООО «ТНИИР-Центр». В ходе работ вокруг обелиска были заложены два шурфа в которых были обнаружены остатки стен и фундаментов собора (Козлова, 2017). Таким образом, до 2019 г. все археологические обследования на городище были ограничены несколькими небольшими шурфами

До 1940-1950-х гг. значительную часть площадки городища занимал собор Успения Божьей Матери.

\footnotetext{
${ }^{6}$ Последнее и наиболее подробное описание археологических памятников Ржева и его округи, а также подробная библиография исторических и археологических трудов, посвященных Ржеву, сделана сотрудником ИА РАН В.С. Нефёдовым (2007. С. 232-234).
} 
По сообщениям тверской епархии, каменный Успенский собор был построен в 1754 г. Он имел пять престолов: в главной части три - Успения Божией Матери, Святителя Арсения, Святого Благоверного Великого князя Михаила Тверского, в придельной части два правый Святого Великого Князя Владимира, левый Святых Благоверных Князей Бориса и Глеба. По данным П.Ф. Симсона, в XVII в. на Соборной Горе было два деревянных храма: собор Успения Пресвятой Богородицы и церковь Мученицы Параскевы Пятницы. По сообщениям дореволюционных краеведов, на горе до 1745 г. также стоял деревянный собор, построенный на месте княжеского сгоревшего дворца. Однако в писцовых книгах Ржева XVII в. эти сведения отсутствуют. К сожалению, ранние изображения храма найти не удалось, а на картах Ржева храм стал изображаться только с конца XVIII в. и в XIX начале XX в.

В связи с упоминаниями храма в письменных источниках XVII в. открытым остается вопрос о времени его возведения на Соборной Горе. А.М. Салимов высказал предположение, что присутствие средневекового храма (Спаса XVI в.) на левобережной Князь-Дмитровской стороне Ржева заставляет предполагать наличие, по крайней ме$\mathrm{pe}$, еще одной древнерусской каменной церкви на противоположной Князь-Федоровской стороне города (Салимов, 2015. С. 229, 230). Исследователю это казалось очевидным из-за того, что на правом высоком берегу Волги (при впадении в нее p. Холынки) существовало городище, на котором находился летописный центр Ржева. По мнению А.М. Салимова, сохранившиеся изображения этого храма свидетельствуют о его создании не ранее XVII в. Все сохранившиеся документы связывают строительство Успенского собора с 1754 г., но А.М. Салимов отмечает, что в соборе хранился антиминс более раннего времени, и на этом основании он предположил, что собор мог быть построен в конце XVII в., но затем перестроен в XVIII в., и уже после перестройки он мог быть вновь переосвящен (Салимов, 2015. С. 234).

В большинстве сообщений о времени строительства собора указывается 1754 г. Этим сведениям противоречит информация, которую в конце XIX в. сообщил в ИАК настоятель собора. В метрике храма, которая хранится в Научном архиве ИИМК РАН, указано, что в церковной описи датой строительства церкви во имя Успения Божьей Матери обозначен 1764 г., и других сведений о строительстве не имеется. В метрике также указаны размеры храма и некоторые сведения о его архитектурных особенностях. «Церковь построена из кирпича, кроме наружного карниза, сделанного из камня и такого же цоколя». Упоминается, что два боковых предела были пристроены к храму в 1853 г. По данным метрики Ржевского городского собора Успения Богородицы, его длина составляла 24 сажени, ширина - 12 саженей (Описание церкви. Ф. Р-3. № 6659).

Собор освящен 15 февраля 1764 г. преосвященным Гавриилом (Петровым), епископом Тверским и Кашинским. Возможно, что информация о дате освящения и послужила для ржевского священника главным аргументом для датировки храма.

Главный собор Ржева также имел 70 метровую колокольню, которая видна была за 20 верст. Колокольня была построена в 1830 г, а в 1853 г. с севера и юга к храму были пристроены два боковых предела (Описание церкви. Ф. Р-3. № 6659). Полностью достроенный собор и колокольня нанесены на план Соборной Горы 1861 г., который хранится в Ржевском музее. Виды собора сохранились на картинах, открытках и фотографиях, в том числе и на первых цветных фотографиях С. М. ПрокудинаГорского. Они позволяют уточнить особенности застройки Соборной Горы и размеры построек.

Храм продолжал действовать до 1930-х гг. ХХ в. После закрытия церкви ее помещения использовались в качестве склада. Несколько позже в храме разместили городской архив. Колокольню власти города стали использовать в качестве парашютной вышки Ржевского аэроклуба. Во время сильной грозы в июле 1931 г. молния ударила в крест над колокольней, и на ней загорелся купол. Этот момент запечатлел ржевский фотограф-любитель. Вероятно, после пожара верхние яруса колокольни были разобраны. На фотоснимках 1941 г. хорошо заметно, что от колокольни сохранился только нижний ярус. В 1941-1943 гг. Ржев стал местом тяжелых боев, и его историческая застройка была в значительной мере уничтожена и затем разобрана. В связи с этим в литературе есть упоминания, что собор разрушили оккупанты. На немецких фотографиях периода оккупации Ржева собор показан в поврежденном виде, но с целыми стенами и сводами. По сведениям местных краеведов, его разрушили в 1950-е гг. при подготовке площадки городища под строительство обелиска. Затем был разобран и дореволюционный каменный мост через ров с западной стороны Соборной Горы.

В августе-сентябре 2019 г. археологической экспедицией Отдела охранной археологии ИИМК РАН были проведены научно-исследовательские археологические работы в виде археологических наблюдений за земляными работами заказчика 
на объекте: «Обелиск советским воинам, погибшим при освобождении г. Ржев от немецко-фашистских захватчиков в годы Великой Отечественной войны», расположенном на территории объекта археологического наследия Городище Ржев «Соборная Гора» (XIII-XVII вв.). Работы проводились с целью выявления на объекте археологического наследия сохранившихся участков культурного слоя и археологических предметов для возможности изучения их методами археологических раскопок. Общая площадь траншей коммуникаций, в которых проводились наблюдения, составляет около 1000 кв. м при ширине полосы обследования от 0,5 до 1 м. Задача археологических исследований на участке обследования заключалась в выявлении, фиксации и исследовании остатков нарушенного археологического слоя, культурных слоев, конструкций и сооружений, массовых и индивидуальных находок путем визуального обследования и фиксации стратиграфии участков, затронутых земляными работами заказчика работ.

В полевых условиях был произведен визуальный осмотр территории на предмет наличия объектов археологического наследия, зачищено 45 траншей для укладки электрокабеля, зафиксирована стратиграфия стенок траншей с целью выявления культурного слоя на территории обследования.

В результате работ были выявлены средневековые культурные слои, остатки фундаментов стен, апсид и крипты Успенского собора середины XVIII в., а также выявлены зоны разрушения памятника. Одной из причин проведения работ на памятнике стали массовые грабительские вторжения в культурный слой городища, которые в течение лета 2019 г. осуществляли местные жители. Безусловно, действия грабителей были стимулированы многочисленными строительными траншеями, которые прорезали культурный слой и окрыли доступ к непотревоженным комплексам и находкам.

Ржевское городище находится в восточной части современного города, в урочище Соборная Гора, на левом берегу р. Волги (рис. 1). Городище располагается на мысу, образовавшемся при впадении р. Холынки в Волгу, на высоте 25-37 м над уровнем воды. С юго-запада оно ограничено руслом Волги, с северо-востока - p. Холынкой, а с юго-востока - ее надпойменной террасой высотой 8-10 м. На планах все городище имеет восьмеркообразную форму и занимает две разноуровневые площадки. Верхняя площадка, расположенная в западной части мыса, имеет подпрямоугольную форму. Размеры верхней площадки городища по осям север-юг и запад-восток составляют $104,64 \times 94,00$ м.

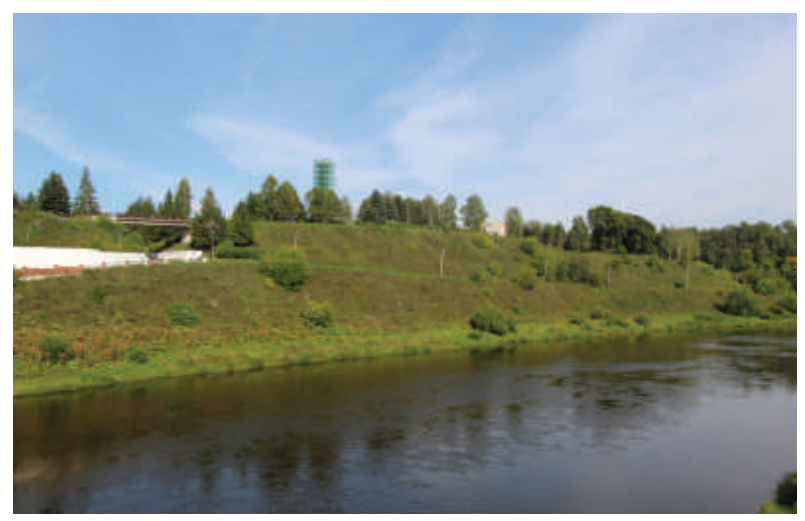

Рис. 1. Ржев. Общий вид на городище Соборная Гора с правого берега Волги

Верхняя часть склонов городища со стороны Волги имеет явные признаки искусственного эскарпа. С напольной западной и северо-западной сторон городище ограничено дугообразным рвом, который соединяет русло р. Холынки с берегом Волги. Первоначальная глубина рва могла быть небольшой, но сейчас он достигает 9 м, так как в XIX$\mathrm{XX}$ вв. его значительно расширили и углубили в качестве внутреннего городского проезда к мосту. В настоящий момент ширина бывшего рва достигает 24 м, и через него перекинут металлический пешеходный мост. В восточной части мыса его верхняя площадка понижается. Перепад высот между верхней и нижней площадками достигает 10 м. Нижняя площадка связывается некоторыми исследователями с территорией первоначального окольного города Ржева. В плане нижняя площадка имеет трапециевидную форму или форму усеченного треугольника с размерами по осям север-юг и запад-восток 147,31 × 114,70 м.

Центральную часть верхней площадки Соборной Горы занимает обелиск, вечный огонь, парк и мемориал с могилами воинов, погибших в годы Великой Отечественной войны. Обелиск частично расположен на развалинах и фундаментах центрального городского собора Успения Пресвятой Богородицы, который был разрушен городскими властями в 1957 г.

В 2019 г. в ходе предварительных наблюдений за строительными работами на городище в урочище Соборная Гора нами было выявлено, что подавляющее большинство участков пешеходных дорожек и траншей коммуникаций, согласно проекту благоустройства, уже были проложены без археологического надзора. Также в восточной части городища были выявлены обширные участки, где верхняя часть культурного слоя и дерна была нарушена строительной техникой 
на глубину от 0,10 до 0,40 м. На всех этих участках были зафиксированы фрагменты средневековой керамики и фрагменты сосудов Нового времени. Так, в восточной части городища или на нижней площадке нами были зафиксированы многочисленные обнажения культурного слоя между пешеходными дорожками. Некоторые из этих обнажений достигали глубины от 0,5 до 1 м. Летом 2019 г. нарушенные строителями участки культурного слоя памятника подверглись интенсивному разграблению жителями города. Следы грабительских ям, оставленных после применения металлодетекторов, продолжали сохраняться на памятнике вплоть до августа-сентября 2019 г.

В самом начале работ на берегу Волги (южный склон Соборной Горы) и к юго-востоку от обелиска был зафиксирован фрагмент бутового фундамента на известковом растворе, который оказался разрушен при строительстве очередной пешеходной дорожки. При дальнейшей расчистке на этом участке был выявлен еще один фрагмент того же фундамента, который относился к южной стене Успенского собора. Далее к востоку от обелиска на месте пешеходной дорожки был выявлен второй фрагмент стены и каменного цоколя собора. Работы на этом были остановлены и о выявлении объекта культурного наследия были проинформированы органы Тверской охраны памятников. Также оказалось, что представители заказчика провели на городище цикл земляных работ по выравниванию площадок для парковки строительной техники и складирования материалов в восточной и юговосточной частях памятника. Особенно сильно от этих действий пострадали участки на внутреннем склоне городища, между верхней (западной) и нижней (восточной) частями Соборной Горы, где колесная техника повредила поверхность церковных апсид и алтарной части Успенского собора. В этом месте памятника сохранившиеся каменные стены собора располагались сразу под дерном.

Всего на западной площадке городища было выявлено шесть фрагментов фундаментов и остатков кирпичных стен. Все они нанесены на схему городища и сопоставлены с планами и размерами Успенского собора (рис. 2). Фрагменты стен храма № 1-3 были обнаружены на современной дневной поверхности к юго-востоку от обелиска. Фрагмент № 1 был выявлен на месте будущей пешеходной дорожки и трассы траншеи освещения № 35, в 34 м к юго-востоку от обелиска. Фрагмент стены сохранился на участке $1,80 \times 1,85$ м. Он находился на предполагаемом месте южной стены Успенского собора. Трасса траншеи разрезала стену перпендикулярно по оси северо-восток-юго-запад. Ширина стены достигала 1,85 м. На поверхности

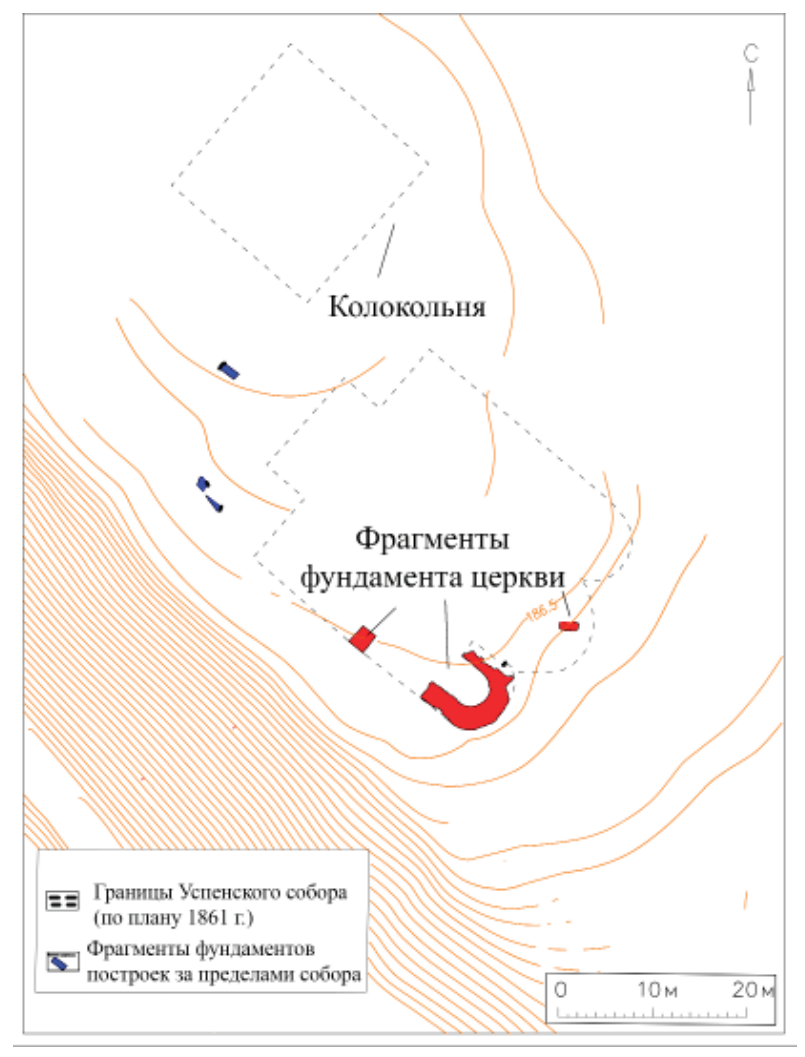

Рис. 2. Ржев. Городище Соборная Гора. Схемареконструкция грании Успенского собора с обозначением открытых частей каменных фундаментов

сохранился один ряд торцевой кирпичной кладки на известковом растворе. Все кирпичи были без клейм (размерами 0,25 × 0,12 × 0,06 м). Поверхность кладки находилась на глубине 186,28-186,56 м БС (рис. 3). К востоку от стены располагалось внутреннее пространство собора, которое было засыпано строительным мусором и кирпичным боем, где попадались обломки шестиугольной метлахской плитки, т. е. поверхность цоколя и современной дневной поверхности может совпадать с уровнем полов в храме. С юго-западной стороны сохранилась облицовка фасада прямоугольными каменными блоками из местного известняка. Размеры блоков: $0,19 \times 0,07$ м, $0,34 \times 0,13$ м, $0,15 \times 0,12$ м. Один из блоков цоколя оказался разрушен строительной техникой, и за ним обнажилась кладка подвальных сводов и провал во внутреннее помещение подвала или крипты, которое находилось под алтарной частью храма. Удалось сфотографировать сохранившуюся часть сводов и северо-восточную внутреннюю перегородку подвального помещения с верхней частью дверного проема. Помещение оказалось заполнено строительным мусором, но следует ожидать, что в нем могут находиться погре- 


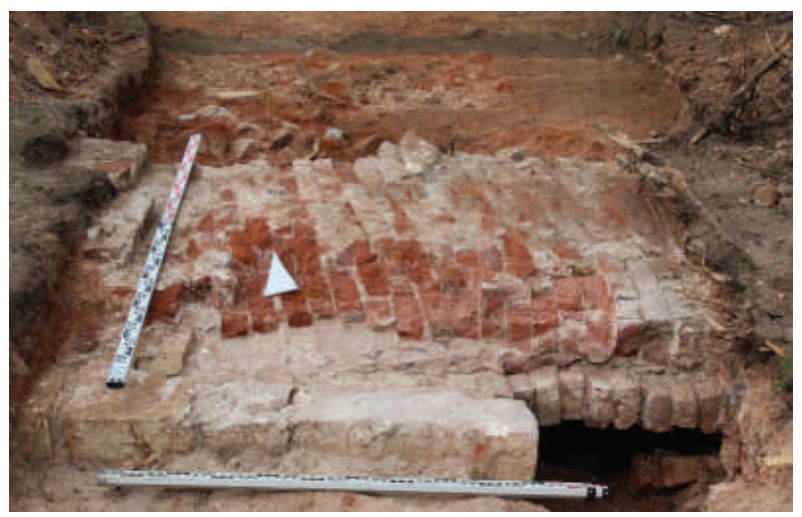

Рис. 3. Ржев. Городище Соборная Гора. Часть стены и цоколя юго-западной стены 1853 г. вместе с обнаживщимся сводом подвального помещения

бения настоятелей собора и богатых прихожан Ржева XVII-XVIII вв. К северу от сохранившейся части свода подземной галереи были выявлены остатки разрушенного свода и остатки переотложенного напольного мощения храма, которое состояло из орнаментированных керамических плиток XIX в.

Фрагмент № 2 был найден за пределами траншей и к востоку от фрагмента № 1, в 40 м к юго-востоку от обелиска. Эти строительные остатки оказались частью апсиды Успенского собора. На дневной поверхности удалось зачистить большую часть юго-восточной апсиды и фрагмент южной стены собора, который являлся продолжением фрагмента № 1. Размеры сохранившегося участка апсиды составляли $7,7 \times 7,7$ м. Ширина фрагмента южной стены на уровне цоколя составляла около 2,1 м (рис. $4 ; 5)$. Каменная облицовка цоколя в один ряд сохранилась с внутренней и с внешней стороны южной стены собора на глубине 186,23-186,34 м БС. Сохранившийся фрагмент стены состоял из трех ря-

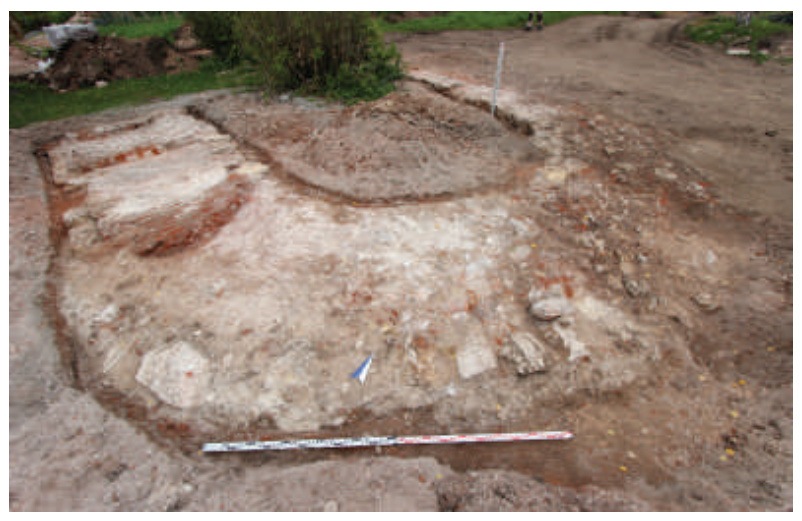

Рис. 4. Ржев. Городище Соборная Гора. Поверхность стены юго-восточной апсиды Успенского собора дов кирпичной кладки на известковом растворе. Все кирпичи были без клейм. Часть из них была нами обмеряна (размеры: $0,25 \times 0,12 \times 0,065 \mathrm{~m} ; 0,24 \times$ $0,125 \times 0,06$ м; $0,235 \times 0,120 \times 0,050$ м). Поверхность верхнего ряда кирпичей зафиксирована на глубине 186,48 м БС. Под кирпичной кладкой и каменным цоколем располагалась поверхность фундамента, который состоял из колотого белого камня (известняка) на известковом растворе.

Фрагмент № 3 был найден за пределами траншей и к северо-востоку от фрагментов № 1 и 2 , в 43 м к юго-востоку от обелиска. Он представлял собой фрагмент фундаментной стенки размерами $1,75 \times$ 0,63 м и высотой около 0,4-0,5 м. Поверхность стены располагалась на уровне 186,44 м БС. Сама фундаментная стена была сложена из колотых камней на известковом растворе. Сорее всего, она относится к северо-восточной аспсиде собора (рис. 2).

На участке в 32 м к югу от обелиска, на месте, где строители вырыли траншею под укладку цементной подушки и мощения, был обнаружен фрагмент № 6 бутового каменного фундамента. Он был сложен из колотых кусков белого песчаника на известковом растворе. В западной стенке траншеи был зафиксирован поперечный разрез этого фундамента по оси север-юг, а в северо-западной стенке - продольный разрез фундамента по оси запад-восток. Во время осмотра траншеи под дерном нашли: медную монету начала XIX в. и древнерусское пряслице из розового овруческого шифера XII-XIII вв. (рис. 6). Пряслице найдено в слое, переотложенном фундаментными ямами собора, но на всем пространстве городища оно оказалось единственной древнерусской находкой домонгольского времени.

Фрагмент фундамента № 4 был обнаружен на дне траншеи, на участке в 28 м к юго-востоку от обелиска. Этот объект представлял собой два отрезка фундаментных стенок, которые располагались под прямым углом друг к другу. Одна из них находилась по оси северо-восток-юго-запад, вторая - северо-запад-юго-восток. Скорее всего, они представляют собой внутреннюю часть югозападного угла постройки, которая предшествовала Успенскому собору 1754-1764 гг. Размеры этого участка составляли $1,30 \times 0,93$ м. Поверхность фундамента находилась на глубине 186,09-186,17 м БС. Фундаментная стенка была сложена из колотых кусков известняка белого цвета на известковом растворе. Этот фрагмент, как и фрагмент № 6, расположен за пределами основного объема собора, но на одной оси с южной стеной его пристройки 1853 г. Можно предположить, что 


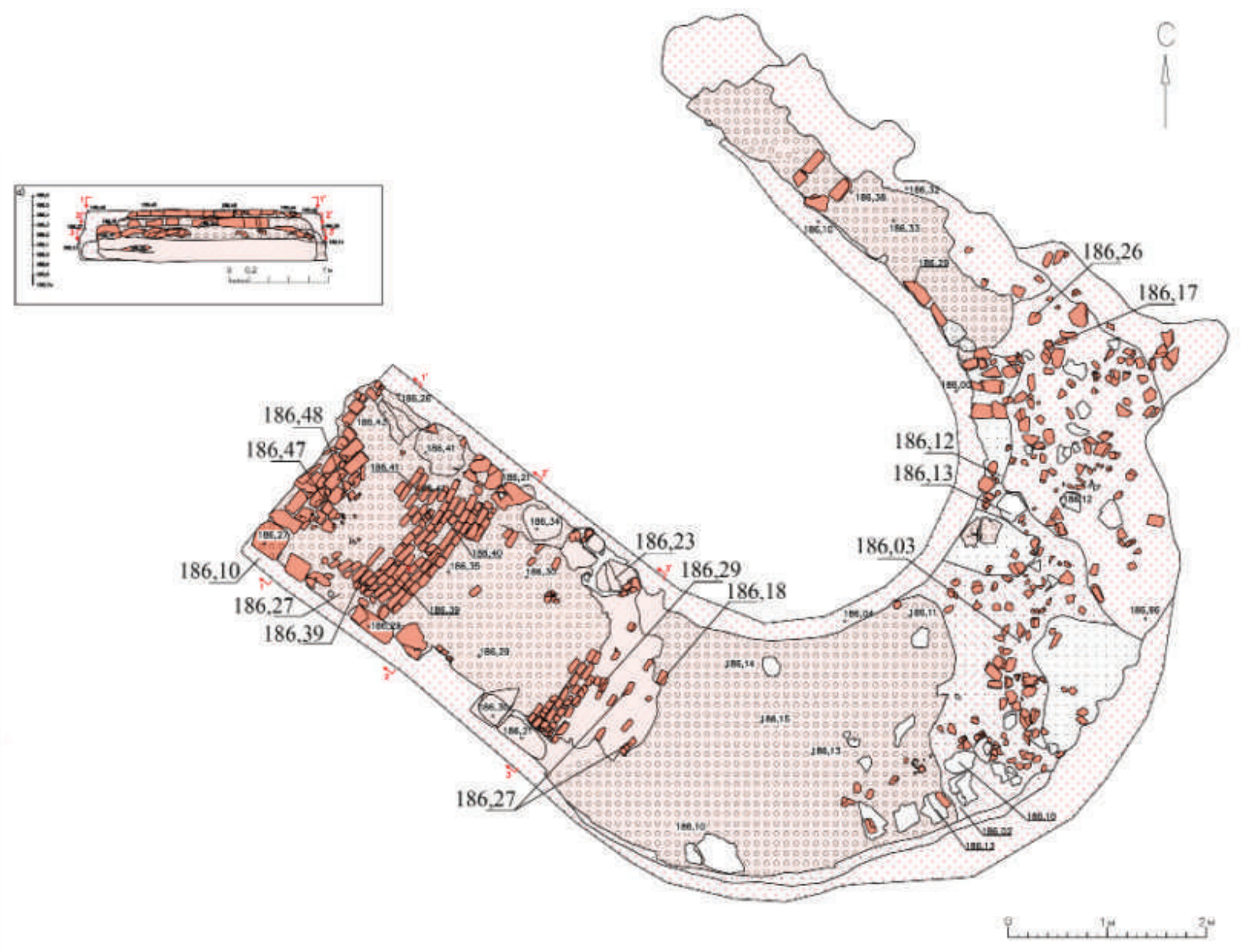

Рис. 5. Ржев. Городище Соборная Гора. План и разрез поверхности стены юго-восточной апсиды Успенского собора

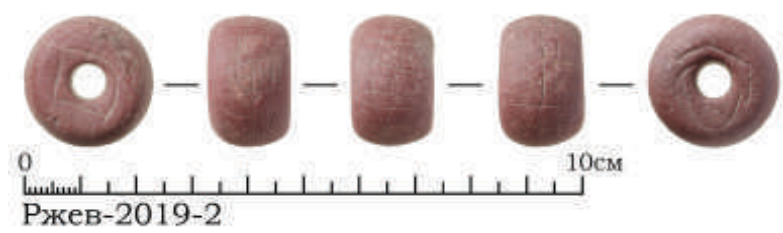

Рис. 6. Ржев. Древнерусское шиферное пряслице XII-XIII вв. с граффити

первоначально для пристройки 1853 г. заложили фундамент большего размера, чем был использован в последствии, или то, что стены пристройки были поставлены на фундаменты более раннего времени. В таком случае фундаментные стены могут быть остатками более раннего храма, который, вероятно, был первым каменным собором на этом месте.

Последний фрагмент каменного фундамента был найден на дне траншеи участка в 10,9 м к юго-востоку от обелиска и к северу от фрагмента № 4, на глу- бине 186,60 м БС, и представлял собой скопление крупных камней на известковом растворе, длиной 1,4 м. Этот фрагмент располагался в 7-8 м к западу от предполагаемого места расположения крыльца собора и в 13 м к западу от предполагаемого места расположения западной стены собора. Следовательно, последний фрагмент кладки не мог принадлежать к фундаментным стенам 1754-1764 г.

Обнаруженные фрагменты фундаментных стен позволили установить точное расположение Успенского собора на площадке городища, выяснить степень сохранности этого памятника и поставить вопрос о наличии в северо-западной части городища ранних каменных построек, предшествующих строительству каменного Успенского собора.

В остальной части городища слой прослеживался в стенках траншей, которые очень редко доходили до уровня материка. Например, в разрезах траншей, которые пересекали центральную часть городища с запада на восток, был прослежен крутой склон 
между северо-западной и юго-восточной площадками городища. Этот участок оказался сглажен мощными слоями строительного мусора, которые остались после строительства и разрушения каменного собора в середине XVIII - середине XX в. При фиксации стенок траншей, в которых отразилась стратиграфия верхней части культурных напластований, создалось впечатление, что склон образовался на месте значительных земляных укреплений, которые отделяли первоначальную площадку крепости от юговосточной части мыса.

Одной из важных особенностей стратиграфии городища оказались появляющиеся в разных частях памятника слои мешаного суглинка краснокоричневого цвета. Толщина этого слоя могла достигать 0,5 м. Этот слой лежал в толще культурных напластований, перекрывая более древние прослойки. При нанесении всех участков этого слоя на общий план памятника оказалось, что слой представляет собой остатки узких и протяженных насыпей, сложенных из однородного красно-коричневого суглинка. Главным образом эти насыпи были выявлены по краю площадки и по всему периметру Соборной Горы (рис. 7). Некоторые участки этого слоя были связаны с участками пожаров и прослоек угля, а другие с находками предметов вооружения XVII в. (рис. 8). Суммируя все наблюдения над распространением этого слоя, можно сделать вывод, что он является остатками засыпки конструкций деревянных укреплений. Именно эти фортификационные сооружения, которые называли тарасами или городнями, располагались по периметру площадки крепости.

В нескольких местах в центральной части юговосточной площадки городища на глубине 1 м от современной поверхности коммуникационные траншеи достигли материкового слоя. Он представлял очень плотный и не потревоженный светло-коричневый суглинок. Этот слой суглинка залегает поверх известняковой плиты, на которой расположено городище, а сверху его перекрывает тонкий слой промытого серо-желтого мелкозернистого песка (предматерик). Из этой прослойки песка происходят несколько находок кремневых отщепов, предположительно эпохи мезолита.

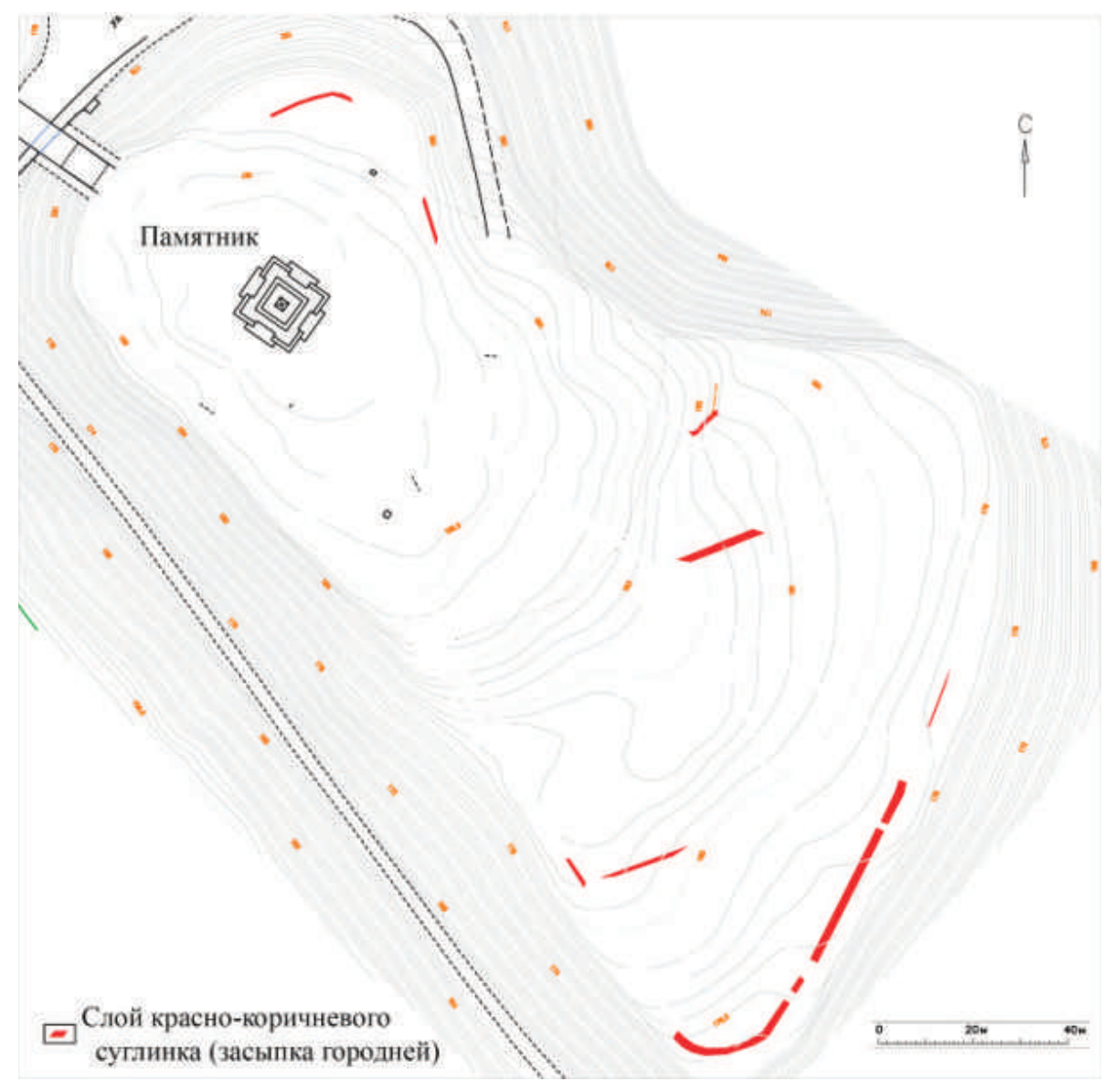

Рис. 7. Ржев. План городища Соборная Гора с обозначением расположения слоя засыпки из красно-коричневой глинь 


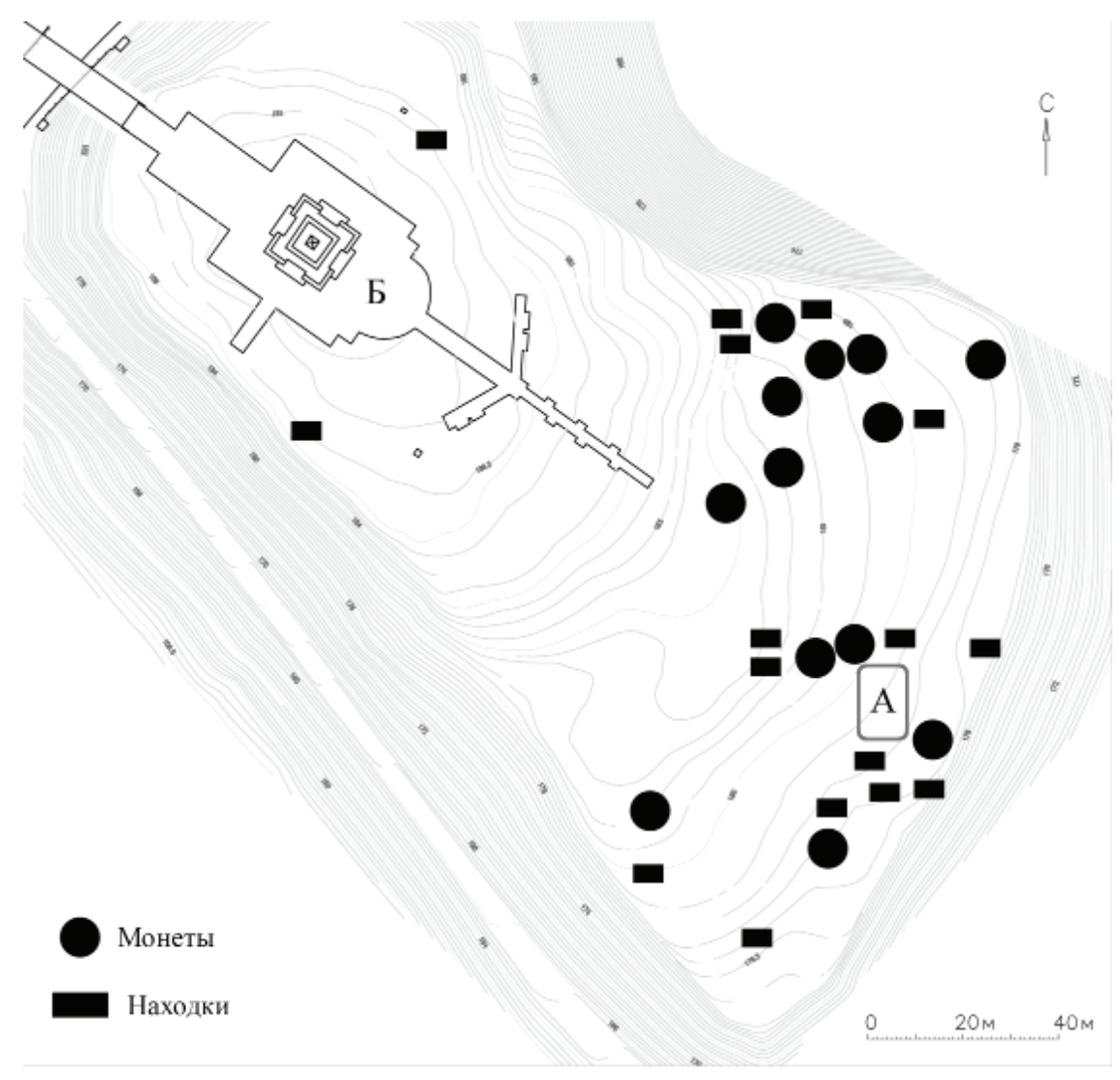

Рис. 8. План ржевского городища Соборная Гора с указанием мест находок монет XV-XVII вв. и средневековых находок XIII - начала XVII в.: A - место грабительских сборов монет; Б - мемориальный комплекс памяти погибших в годы Великой Отечественной войнь

На городище было собрано 158 индивидуальных находок и 570 фрагментов гончарной керамики. Часть из них найдена в траншеях, часть - на участках с нарушенным культурным слоем между траншеями. К наиболее ранней группе предметов следует отнести каменные орудия из местного красноватого кремня, которые могут быть датированы эпохой мезолита или неолита. Большая часть кремневых орудий была найдена на дне траншей и даже на поверхности материка или в предматерике - слое серо-желтого песка. К ним относятся: пластина серо-коричневатого кремня со следами сколов (№ 24), пластина розовосероватого кремня со следами сколов пластин на внешней стороне (№ 32), пластина бордового кремня со следами сколов пластин на внешней стороне (№ 33), скол бордового кремня с пластины со следами обработки (№ 34), скол темно-розового с белыми прожилками кремня подпрямоугольной формы со следами сколов на внешней стороне (№ 35), отщеп темно-розового с серыми полосами кремня, подквадратной формы (№ 36), нуклеус бордового кремня со следами сколов пластин (№ 38), отщеп буро-серого полосатого кремня с «забитым» ретушью краем (№ 39), пластина непрозрачного коричневого с бордовыми пятнами кремня (№ 149), обломок пластины красно-бурого кремня (№ 151), отщеп краснобурого кремня (№ 152), пластина красно-бурого кремня (№ 153), подквадратный отщеп (?) краснобурого с серой полосой кремня (№ 154). Всего на участках № 1-3, 5, 11 и 12 было найдено 13 отщепов, пластин и сколов. Главным образом эти находки концентрировались на южном краю городища, вдоль берега Волги.

К редким находкам следует отнести обломок шлифованного топора из серого камня с отверстием. Аналогичные топоры связаны с бытованием Фатьяновской культуры, которую относят к эпохе бронзы, и, следовательно, его можно датировать II-I тыс. до н.э. (№ 45) (рис. 9).

Древнерусский период истории города оказался представлен крайне скудно. В верхней части заполнения бутового фундамента на участке № 1 найдено пряслице цилиндрической формы из овручского красного шифера с процарапанным орнаментом на боковой и торцевых сторонах. Пряслице, скорее всего, оказалось перемещено из нижней 


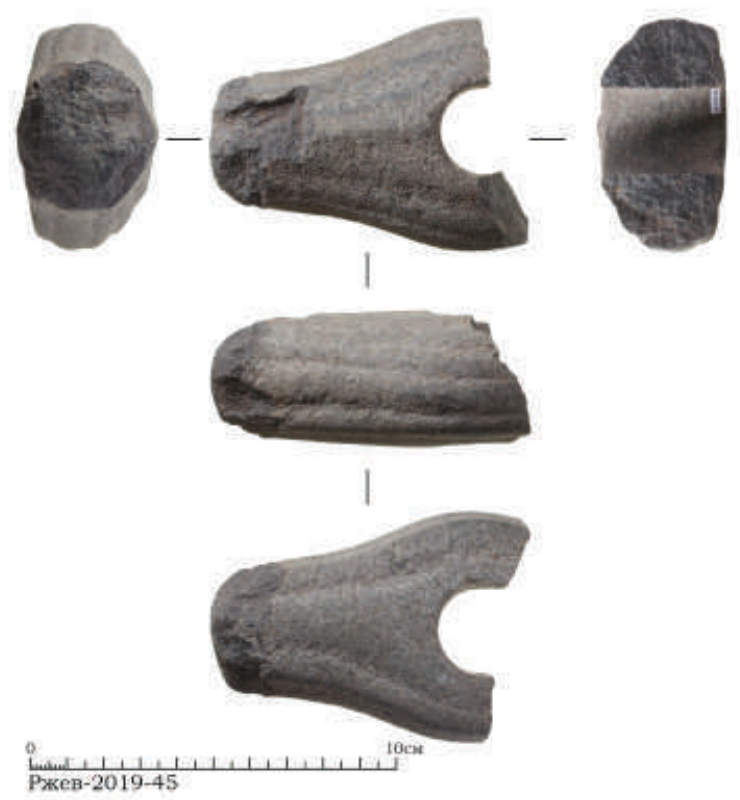

Рис. 9. Ржев. Городище Соборная Гора. Каменный топор. Фатьяновская культура

части культурных напластований в верхние во время строительства Успенского собора, но на данный момент это единственная находка на городище, которая может быть отнесена к XII-XIII вв. и которая косвенно подтверждает древнерусское происхождение памятника (рис. 6). Ключ от цилиндрического замка, тип В или В1 (№ 40) тоже может быть отнесен к числу древнерусских находок, но широкие рамки бытования ключей этого типа (c XII по XV в.) не позволяют отнести эту находку к раннему периоду существования городища (рис. 10). В качестве редкой находки следует упомянуть средневековую свинцовую печать с изображением святого. Подобными печатями (буллами) в древнерусский период скреплялись официальные государственные, административные и церковные документы. Первая подобная находка на ржевском городище указывает на присутствие на памятнике административного центра. Так же к эпохе Средневековья можно отнести коромысло от весов, которое было найдено в южном углу нижней (восточной) площадки городища.

Большинство находок из слоя относятся к позднесредневековому периоду существования крепости и города, к эпохе Смуты. XIV-XVI вв. можно датировать весы из медного сплава, перстень и каменный крестик из сланца серого цвета (рис. 11-13). Более многочисленной категорией оказались предметы вооружения и снаряжения всадника, обнаруженные главным образом в юго-восточной части юговосточной площадки городища (рис. 8). Там были

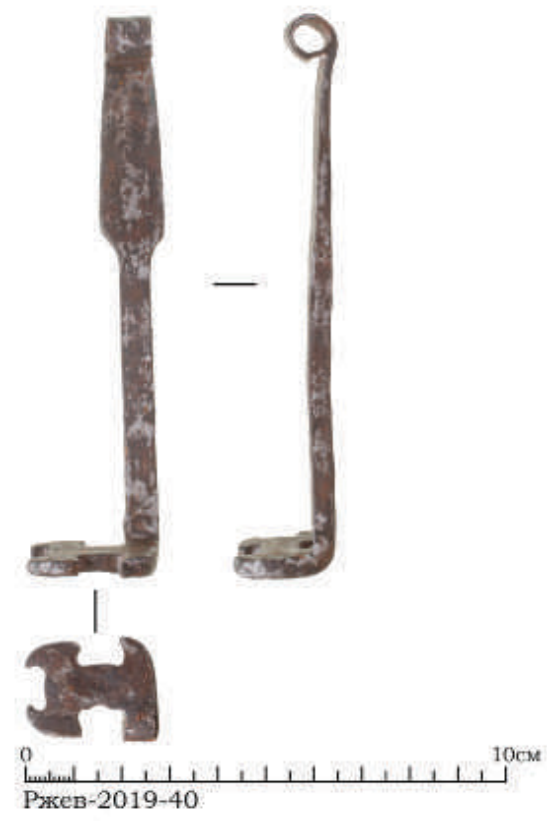

Рис. 10. Ржев. Городище Соборная Гора. Древнерусский железный ключ типа $B$

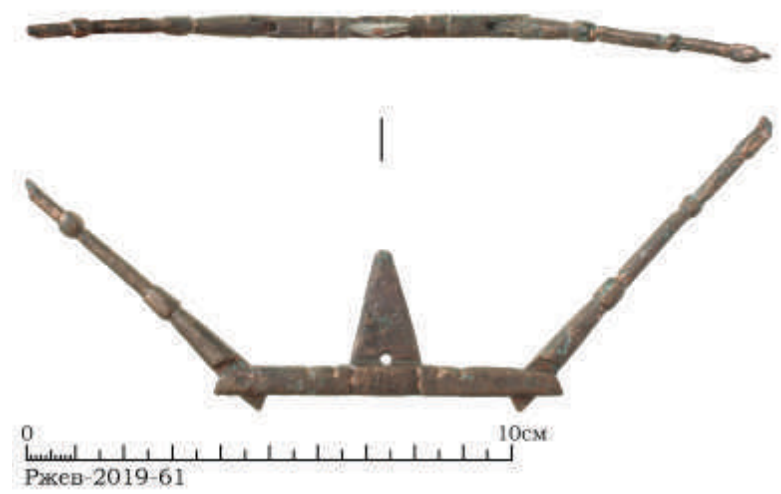

Рис. 11. Ржев. Городище Соборная Гора.

Средневековое коромысло от весов

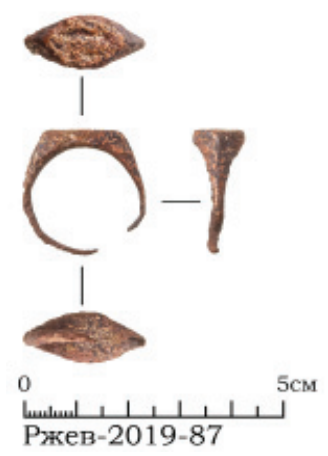

Рис. 12. Ржев. Городище Соборная Гора. Средневековый перстень из медного сплава 


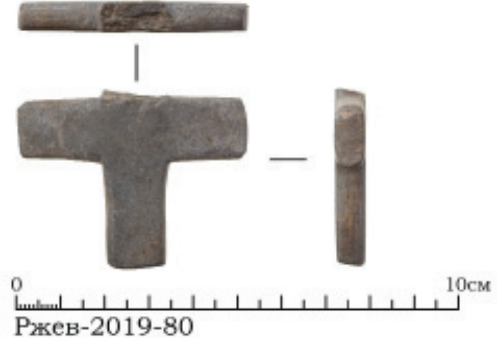

Рис. 13. Ржев. Городище Соборная Гора.

Средневековый каменный крестик

найдены круглые свинцовые пули с остатками литников, железное ядро от фальконета, удила, фрагмент сабельного клинка. Можно предположить, что такая концентрация предметов вооружения XVII в. связана с событиями Смутного времени или штурмом крепости отрядом пана Лисовского.

В ходе работ экспедиции помимо прочих артефактов были обнаружены нумизматическая и сфрагистическая коллекции, имеющие важное значение для уточнения датировки памятника и характеристики социально-экономических процессов, происходивших здесь в Средневековье и Новое время. Непосредственно во время наблюдения за земляными работами было найдено 29 монет и половина сломанной вдоль канала вислой печати. Также у местных жителей удалось зарегистрировать еще 37 монет и две вислые печати, обнаруженные в пределах памятника в ходе нелегального металлопоиска (табл. 1) 7 .

Найденные монеты концентрировались в восточной зоне городища несколькими группами на северном и восточном краю склона, а также в центральной части нижней площадки (рис. 14). Их большая серия зафиксирована сразу под дерном в местах, где строительная техника срезала верхние $0,10-0,20$ м культурного слоя, представлявшего темно-серую гумусированную супесь. Другие монеты были обнаружены на дне траншей в остатках древесного тлена, возможно, связанного с постройками XVI-XVII вв. В траншее № 17 большинство денежных знаков выявлено или на ее дне, под прослойками краснокоричневого суглинка, или в слое темно-серой гумусированной супеси, перемешанной с кусками суглинка, т. е. в слое, перекрытом остатками вала. Монеты, обнаруженные в ходе грабительских раскопок, концентрировались в восточной части нижней площадки городища. Атрибуция нумизматических коллекций,

${ }^{7}$ Находчиками были указаны точные места обнаружения монет и печатей, часть из которых была передана авторам для дальнейшего изучения.

\section{Сфрагистический материал}

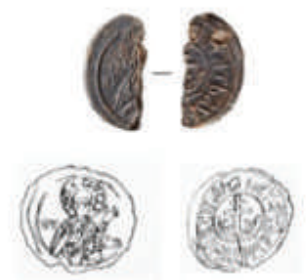

Новгород Великиі̆. Плотиццкий юонец, Aнтонье монастырь, 50-60-e r. XV в.
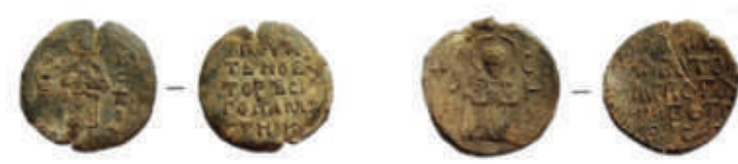

Новый Торг. Печати наместника времени архиепископ Моисея. Первая половина $\mathrm{XIV}$ в.

Рис. 14. Ржев. Городище Соборная Гора. Сфрагистические находки

полученных в ходе надзора и зарегистрированных у местных жителей, позволяет заключить, что в целом они имеют идентичный состав, что позволяет в дальнейшем рассматривать их как единый комплекс.

Старшим в составе коллекции является джучидский пул, отчеканенный в 743 г. х. (1342 р. х.) в Сарай ал-Джедиде ${ }^{8}$. Среди исследователей преобладает мнение, что денежные знаки, изготовленные не из благородных металлов в эпоху Средневековья, как правило, обслуживали только внутренние денежные рынки государств-эмиссионеров, не являясь конвертируемой валютой. Для их обращения за рубежом в качестве средства расчета требовалась законодательная «принудительная» регламентация или устойчивые торговые связи со странами, в которых такие монеты имели хождение (Петров, 1997. C. 16, 17).

В пределах русских княжеств находки джучидских пул достаточно редки. Наибольшее их количество зарегистрировано в Рязанской земле. На территории Москвы и Подмосковья ${ }^{9}$, куда подобные денежные знаки начинают попадать во второй половине XIV в., известно всего несколько

\footnotetext{
${ }^{8}$ Определение К. Хромова, за что авторы выражают ему благодарность.

${ }^{9}$ Область распространения джучидских дирхемов, обращавшихся на Руси в качестве расчетного средства, не включает в себя территорию к северу от Москвы (Волков, 2003, С. 40; 2004. С. 353, 355).
} 


\section{Таблиияа 1. Монетные находки (по классификации П. Г. Гайдукова (1993))}

\begin{tabular}{|c|c|c|c|c|c|c|c|c|}
\hline № & Эмитент & Правитель & Номинал & $\begin{array}{c}\text { Дата } \\
\text { чеканки, ге. }\end{array}$ & $\begin{array}{l}\text { Место } \\
\text { чеканки }\end{array}$ & Металл & $\begin{array}{c}B e c \\
2\end{array}$ & Tun \\
\hline 1 & Улус Джучи & & Пул & $\begin{array}{c}743 \text { г. х. }(1342 \\
\text { р. х.) }\end{array}$ & $\begin{array}{c}\text { Сарай ал- } \\
\text { Джедид }\end{array}$ & Медь & $?$ & \\
\hline 2 & $\begin{array}{c}\text { Великое княжество } \\
\text { Московское (?) }\end{array}$ & $?$ & Пуло & $\begin{array}{c}\text { Конец XIV - } \\
\text { первая пол. } \\
\text { XV в. }\end{array}$ & Москва (?) & Медь & 1,185 & \\
\hline 3 & $\begin{array}{c}\text { Городенское удельное } \\
\text { княжество }\end{array}$ & Борис Александрович & Пуло & $1425-1461$ & Городен & Медь & 1,940 & $\Gamma-368$ \\
\hline 4 & $\begin{array}{c}\text { Тверское великое } \\
\text { княжество }\end{array}$ & Михаил Борисович & Пуло & $1461-1466$ & Тверь & Медь & 1,240 & $\Gamma-6$ \\
\hline 5 & $\begin{array}{c}\text { Тверское великое } \\
\text { княжество }\end{array}$ & Михаил Борисович & Пуло & $1461-1466$ & Тверь & Медь & 1,180 & $\Gamma-7$ \\
\hline 6 & $\begin{array}{c}\text { Тверское великое } \\
\text { княжество }\end{array}$ & Михаил Борисович & Пуло & $1461-1466$ & Тверь & Медь & 1,220 & $\Gamma-138$ \\
\hline 7 & $\begin{array}{c}\text { Тверское великое } \\
\text { княжество }\end{array}$ & Михаил Борисович & Пуло & $1461-1473$ & Тверь & Медь & 0,695 & $\Gamma-28$ \\
\hline 8 & $\begin{array}{c}\text { Тверское великое } \\
\text { княжество }\end{array}$ & Михаил Борисович & Пуло & $1467-1473$ & Тверь & Медь & 1,155 & $\Gamma-151$ \\
\hline 9 & $\begin{array}{c}\text { Тверское великое } \\
\text { княжество }\end{array}$ & Михаил Борисович & Пуло & $1467-1473$ & Тверь & Медь & 1,300 & $\Gamma-275$ \\
\hline 10 & $\begin{array}{c}\text { Тверское великое } \\
\text { княжество }\end{array}$ & Михаил Борисович & Пуло & $1467-1473$ & Тверь & Медь & $?$ & $\Gamma-283$ \\
\hline 11 & $\begin{array}{c}\text { Тверское великое } \\
\text { княжество }\end{array}$ & Михаил Борисович & Пуло & $1467-1473$ & Тверь & Медь & 2,290 & $\Gamma-294$ \\
\hline 12 & $\begin{array}{c}\text { Тверское великое } \\
\text { княжество }\end{array}$ & Михаил Борисович & Пуло & $1474-1479$ & Тверь & Медь & 1,190 & $\Gamma-83$ \\
\hline 13 & $\begin{array}{c}\text { Тверское великое } \\
\text { княжество }\end{array}$ & Михаил Борисович & Пуло & $1474-1479$ & Тверь & Медь & 0,630 & $\Gamma-159$ \\
\hline 14 & $\begin{array}{c}\text { Тверское великое } \\
\text { княжество }\end{array}$ & Михаил Борисович & Пуло & $1480-1485$ & Тверь & Медь & 0,570 & $\Gamma-268$ \\
\hline 15 & $\begin{array}{c}\text { Тверское великое } \\
\text { княжество }\end{array}$ & Иван Иванович & Пуло & $1485-1490$ & Тверь & Медь & 1,320 & $\Gamma-308$ \\
\hline 16 & $\begin{array}{c}\text { Тверское великое } \\
\text { княжество }\end{array}$ & Иван Иванович & Пуло & $1485-1490$ & Тверь & Медь & 0,710 & $\Gamma-343$ \\
\hline
\end{tabular}




\begin{tabular}{|c|c|c|c|c|c|c|c|c|}
\hline № & Эмитент & Правитель & Номинал & $\begin{array}{c}\text { Дата } \\
\text { чеканки, ге. }\end{array}$ & $\begin{array}{l}\text { Место } \\
\text { чеканки }\end{array}$ & Металл & $\begin{array}{c}\mathrm{Bec}, \\
2\end{array}$ & Tun \\
\hline 17 & $\begin{array}{c}\text { Тверское великое } \\
\text { княжество }\end{array}$ & Иван Иванович & Пуло & $1485-1490$ & Тверь & Медь & 0,720 & $\begin{array}{c}\Gamma-306- \\
327\end{array}$ \\
\hline 18 & $\begin{array}{c}\text { Тверское великое } \\
\text { княжество }\end{array}$ & Василий Иванович & Пуло & $1490-1491$ & Тверь & Медь & 0,650 & $\Gamma-349$ \\
\hline 19 & Русские земли (?) & $?$ & Пуло & $?$ & $?$ & Медь & 0,210 & $?$ \\
\hline 20 & $\begin{array}{c}\text { Великое княжество } \\
\text { Всея Руси }\end{array}$ & $\begin{array}{c}\text { Василий III или } \\
\text { Иван IV }\end{array}$ & Пуло & Ок. $1490-1570$ & Тверь & Медь & 0,320 & $\Gamma-358 ?$ \\
\hline 21 & $\begin{array}{c}\text { Великое княжество } \\
\text { Всея Руси }\end{array}$ & $\begin{array}{c}\text { Василий III или } \\
\text { Иван IV }\end{array}$ & Пуло & Ок. 1490-1570 & Тверь & Медь & 0,500 & $\Gamma-358$ \\
\hline 22 & $\begin{array}{c}\text { Великое княжество } \\
\text { Всея Руси }\end{array}$ & $\begin{array}{c}\text { Василий III или } \\
\text { Иван IV }\end{array}$ & Пуло & Ок. $1490-1570$ & Тверь & Медь & $?$ & $\Gamma-358$ \\
\hline 23 & $\begin{array}{c}\text { Великое княжество } \\
\text { Всея Руси }\end{array}$ & $\begin{array}{c}\text { Василий III или } \\
\text { Иван IV }\end{array}$ & Пуло & Ок. 1490-1570 & Тверь & Медь & $?$ & $\Gamma-358$ \\
\hline 24 & $\begin{array}{c}\text { Великое княжество } \\
\text { Всея Руси }\end{array}$ & $\begin{array}{c}\text { Василий III или } \\
\text { Иван IV }\end{array}$ & Пуло & Ок. $1490-1570$ & Тверь & Медь & 0,380 & $\Gamma-358$ \\
\hline 25 & $\begin{array}{c}\text { Великое княжество } \\
\text { Всея Руси }\end{array}$ & $\begin{array}{c}\text { Василий III или } \\
\text { Иван IV }\end{array}$ & Пуло & Ок. $1490-1570$ & Тверь & Медь & $?$ & $\Gamma-360$ \\
\hline 26 & $\begin{array}{c}\text { Великое княжество } \\
\text { Всея Руси }\end{array}$ & $\begin{array}{c}\text { Василий III или } \\
\text { Иван IV }\end{array}$ & Пуло & Ок. $1490-1570$ & Тверь & Медь & $?$ & $\begin{array}{c}\Gamma-361 \\
\text { или } \\
362 \\
\end{array}$ \\
\hline 27 & $\begin{array}{c}\text { Великое княжество } \\
\text { Всея Руси. Русское } \\
\text { Царство }\end{array}$ & Иван IV & Пуло & $\begin{array}{c}\text { Ок. } 1530- \\
1560-\mathrm{e}\end{array}$ & Москва & Медь & 0,335 & $\Gamma-405$ \\
\hline 28 & $\begin{array}{c}\text { Великое княжество } \\
\text { Всея Руси. Русское } \\
\text { Царство }\end{array}$ & Иван IV & Пуло & $\begin{array}{c}\text { Ок. } 1530- \\
1560-\mathrm{e}\end{array}$ & Москва & Медь & 0,350 & $\Gamma-407$ \\
\hline 29 & $\begin{array}{c}\text { Великое княжество } \\
\text { Всея Руси. Русское } \\
\text { Царство }\end{array}$ & Иван IV & Пуло & $\begin{array}{c}\text { Ок. } 1530- \\
1560-\mathrm{e}\end{array}$ & Москва & Медь & 0,275 & $?$ \\
\hline 30 & $\begin{array}{c}\text { Великое княжество } \\
\text { Всея Руси }\end{array}$ & $\begin{array}{c}\text { Василий III или } \\
\text { Иван IV }\end{array}$ & Пуло & $\begin{array}{c}\text { Конец } \\
\text { XV-1560-е }\end{array}$ & Новгород & Медь & 0,245 & $\Gamma-438$ \\
\hline 31 & $\begin{array}{c}\text { Великое княжество } \\
\text { Всея Руси }\end{array}$ & $\begin{array}{c}\text { Василий III или } \\
\text { Иван IV }\end{array}$ & Пуло & XV в. & Псков & Медь & 0,290 & $\Gamma-444 ?$ \\
\hline 32 & $\begin{array}{c}\text { Великое княжество } \\
\text { Всея Руси }\end{array}$ & $\begin{array}{c}\text { Василий III или } \\
\text { Иван IV }\end{array}$ & Пуло & $\begin{array}{c}\text { Конец XV- } \\
\text { XVI в. }\end{array}$ & $?$ & Медь & 0,240 & $?$ \\
\hline
\end{tabular}


Бюллетень ИИМК РАН. № 10

\begin{tabular}{|c|c|c|c|c|c|c|c|c|}
\hline № & Эмитент & Правитель & Номинал & $\begin{array}{c}\text { Дата } \\
\text { чеканки, ге. }\end{array}$ & $\begin{array}{l}\text { Место } \\
\text { чеканки }\end{array}$ & Металл & $\begin{array}{c}B e c \\
2\end{array}$ & Tun \\
\hline 33 & $\begin{array}{c}\text { Великое княжество } \\
\text { Всея Руси }\end{array}$ & $\begin{array}{c}\text { Василий III или } \\
\text { Иван IV }\end{array}$ & Пуло & $\begin{array}{c}\text { Конец XV- } \\
\text { XVI в. }\end{array}$ & $?$ & Медь & 0,320 & $?$ \\
\hline 34 & $\begin{array}{c}\text { Великое княжество } \\
\text { Всея Руси }\end{array}$ & $\begin{array}{c}\text { Василий III или } \\
\text { Иван IV }\end{array}$ & Пуло & $\begin{array}{c}\text { Конец XV- } \\
\text { XVI в. }\end{array}$ & $?$ & Медь & $?$ & $?$ \\
\hline 35 & $\begin{array}{c}\text { Великое княжество } \\
\text { Всея Руси. Русское } \\
\text { Царство }\end{array}$ & Иван IV & Денга & $1535-1547$ & Москва & Серебро & $?$ & $\begin{array}{c}\text { ГКХ- } \\
48\end{array}$ \\
\hline 36 & $\begin{array}{c}\text { Великое княжество } \\
\text { Всея Руси. Русское } \\
\text { Царство }\end{array}$ & Иван IV & Денга & $1535-1547$ & Москва & Серебро & $?$ & ГКХ-62 \\
\hline 37 & $\begin{array}{c}\text { Великое княжество } \\
\text { Всея Руси. Русское } \\
\text { Царство }\end{array}$ & Иван IV & Денга & $1570-\mathrm{e}$ & Москва & Серебро & $?$ & ГКХ-78 \\
\hline 38 & $\begin{array}{c}\text { Великое княжество } \\
\text { Всея Руси. Русское } \\
\text { Царство }\end{array}$ & Иван IV & Копейка & $1550-e-1560-e$ & Новгород & Серебро & $?$ & ГКХ-7 \\
\hline 39 & $\begin{array}{c}\text { Великое княжество } \\
\text { Всея Руси. Русское } \\
\text { Царство }\end{array}$ & Иван IV & Копейка & $1580-\mathrm{e}$ & Псков & Серебро & $?$ & ГКХ-29 \\
\hline 40 & $\begin{array}{c}\text { Великое княжество } \\
\text { Всея Руси. Русское } \\
\text { Царство }\end{array}$ & Борис Годунов & Копейка & 1599 & Новгород & Серебро & $?$ & $\begin{array}{l}\Gamma К Х- \\
202 ?\end{array}$ \\
\hline 41 & $\begin{array}{c}\text { Великое княжество } \\
\text { Всея Руси. Русское } \\
\text { Царство }\end{array}$ & Борис Годунов & Копейка & 1601 & Новгород & Серебро & $?$ & $\begin{array}{c}\Gamma К Х- \\
213\end{array}$ \\
\hline 42 & $\begin{array}{c}\text { Великое княжество } \\
\text { Всея Руси. Русское } \\
\text { Царство }\end{array}$ & Борис Годунов & Копейка & 1602 & Новгород & Серебро & $?$ & $\begin{array}{c}\text { ГКХ- } \\
224\end{array}$ \\
\hline 43 & $\begin{array}{c}\text { Великое княжество } \\
\text { Всея Руси. Русское } \\
\text { Царство }\end{array}$ & Борис Годунов (?) & Копейка & $1598-1605$ & Новгород (?) & Серебро & $?$ & $?$ \\
\hline 44 & Русское Царство & Михаил Федорович & Копейка & $1613-1617$ & Москва & Серебро & $?$ & $\begin{array}{c}\Gamma К X- \\
355\end{array}$ \\
\hline 45 & Русское Царство & Михаил Федорович & Копейка & $1613-1617$ & Москва & Серебро & 0,320 & $\begin{array}{c}\Gamma К \mathrm{X}- \\
361\end{array}$ \\
\hline 46 & Русское Царство & Михаил Федорович & Копейка & $1620-\mathrm{e}$ & Москва & Серебро & $?$ & $?$ \\
\hline 47 & Русское Царство & Михаил Федорович & Копейка & $1621-1625$ & Москва & Серебро & $?$ & $\begin{array}{c}\text { ГКХ- } \\
432\end{array}$ \\
\hline
\end{tabular}




\begin{tabular}{|c|c|c|c|c|c|c|c|c|}
\hline № & Эмитент & Правитель & Номинал & $\begin{array}{c}\text { Дата } \\
\text { чеканки, гг. }\end{array}$ & $\begin{array}{l}\text { Место } \\
\text { чеканки }\end{array}$ & Металл & $\begin{array}{c}B e c, \\
2\end{array}$ & Tun \\
\hline 48 & Русское Царство & Михаил Федорович & Копейка & $1630-\mathrm{e}$ & Москва & Серебро & $?$ & $\begin{array}{c}\text { ГКХ- } \\
508\end{array}$ \\
\hline 49 & Русское Царство & Михаил Федорович & Копейка & $1640-\mathrm{e}$ & Москва & Серебро & $?$ & $\begin{array}{c}\Gamma К \mathrm{X}- \\
626\end{array}$ \\
\hline 50 & Русское Царство & Михаил Федорович & Копейка & $1613-1645$ & Москва & Серебро & $?$ & $?$ \\
\hline 51 & Русское Царство (?) & $?$ & Копейка & XVI-XVII вв. & $?$ & Серебро & $?$ & $?$ \\
\hline 52 & Российская империя & Петр I & Полушка & 1721 & & Медь & & \\
\hline 53 & Российская империя & Анна Иоанновна & Денга & 1731 & $\begin{array}{c}\text { Москва } \\
\text { (Красный } \\
\text { двор) }\end{array}$ & Медь & & \\
\hline 54 & Российская империя & Анна Иоанновна & Полушка & 1734 & $\begin{array}{c}\text { Москва } \\
\text { (Плащильная } \\
\text { мельница на } \\
\text { Яузе) }\end{array}$ & Медь & & \\
\hline 55 & Российская империя & Анна Иоанновна & Полушка & 1735 & $\begin{array}{c}\text { Москва } \\
\text { (Плащильная } \\
\text { мельница на } \\
\text { Яузе) }\end{array}$ & Медь & & \\
\hline 56 & Российская империя & Елизавета Петровна & Денга & $1757-1760$ & $?$ & Медь & & \\
\hline 57 & Российская империя & Елизавета Петровна & Копейка & $1757-1760$ & $?$ & Медь & & \\
\hline 58 & Российская империя & Екатерина II & 5 копеек & 1776 & Екатеринбург & Медь & & \\
\hline 59 & Российская империя & Александр I & 2 копейки & 1812 & Колпино & Медь & & \\
\hline 60 & Российская империя & Александр I & 2 копейки & 1813 & Колпино & Медь & & \\
\hline 61 & Российская империя & Александр I & 2 копейки & 1814 & Екатеринбург & Медь & & \\
\hline 62 & Российская империя & Николай I & $\begin{array}{l}1 \text { копейка } \\
\text { серебром }\end{array}$ & 1840 & Екатеринбург & Медь & & \\
\hline 63 & Российская империя & Николай I & $\begin{array}{l}1 / 2 \text { копейки } \\
\text { серебром }\end{array}$ & 1842 & Колпино & Медь & & \\
\hline 64 & Российская империя & Александр II & 2 копейки & 1856 & Екатеринбург & Медь & & \\
\hline 65 & $\begin{array}{c}\text { Германия. Третий } \\
\text { рейх }\end{array}$ & & $\begin{array}{c}5 \text { рейхс- } \\
\text { пфеннигов }\end{array}$ & $1940-1944$ & Берлин & Цинк & & \\
\hline 66 & $\mathrm{CCCP}$ & & 1 копейка & 1940 & Ленинград & $\begin{array}{c}\text { Алюми- } \\
\text { ниевая } \\
\text { бронза }\end{array}$ & & \\
\hline
\end{tabular}


экземпляров (Волков, 2003. С. 40; Зайцев, 2006а С. 56; Гомзин, 2015. С. 156, 157). На сегодняшний день роль пул Золотой Орды в пределах Руси остается неясной. Вероятнее всего, их находки стоит расценивать в качестве свидетельства интенсивных контактов княжеств с Золотой Ордой, но не как местное средство расчета (Гомзин, 2011. С. 212; 2015. С. 156, 157). В пользу такой интерпретации положения пул важным является замечание А.А. Гомзина, отметившего отсутствие на них надчеканок в виде букв или рязанской тамги ${ }^{10}$, которые часто встречаются на серебряных монетах Золотой Орды, участвовавших в русском денежном обращении (Гомзин, 2011. С. 212). Находка пула на Ржевском городище может маркировать наличие в месте его фиксации культурного слоя середины XIV в., а также указывать на активные контакты местного населения с улусом Джучи.

Следующая рассматриваемая монета имеет плохую сохранность, что затрудняет ее точную атрибуцию. На одной из ее сторон виден фрагмент арабографической легенды, а на другой - орнамент в виде завитков. Особенности техники изготовления монетной заготовки, выполненной из расплющенной проволоки, указывают на русское происхождение данного экземпляра ${ }^{11}$.

На Руси медные монеты в конце XIV в. стали чеканить под влиянием денежной системы Золотой Орды. Их массовые находки на археологических памятниках указывают на потребность местного населения в знаках мелких номиналов для проведения розничной торговли, что в свою очередь характеризует особенности экономического развития (Зайцев, 1999. С. 116; 2004. С. 78, 79; Беляев, Гайдуков, 2006. С. 41; Гайдуков, Кренке, 2009. С. 103, 104; Беляев, 2019. 24). Важнейшим сегментом коллекции выступают 16 больших пул, чеканенных в Твери и удельном княжестве Городенском. Старшая из этих монет выпущена во время правления князя Бориса Александровича 1425-1461 гг. в Городене.

Эмиссия князя Михаила Борисовича представлена 11 тверскими пулами, разделяющимися на выделенные П. Г. Гайдуковым пять хронологических групп, охватывающих временной отрезок с 1461 по 1485 гг. (Гайдуков, 1993. С. 49-52, 56). К наиболее раннему выпуску 1461-1466 гг. принадлежат две монеты с указанием имени князя в строчной легенде оборотной

10 Данные знаки являлись своего рода удостоверением, позволявшим использование таких монет.

${ }^{11}$ Известные пулы Золотой Орды изготовлялись на специально вырезанных монетных кружках. стороны $(\Gamma-6,7)$ и одна с обозначением названия города (Г-138). Периодом с 1467 по 1473 г. датируются четыре пула, одно из которых несет название города (Г-151) и три без указания города и имени князя (Г-275, 283, 294). Более широко 1461-1473 гг. определяется экземпляр типа V варианта 1 с именем князя (Г-28). Такие денежные знаки являлись переходными от среднего веса 1,4 к 1,3 г, что и обусловило особенности их хронологии (Гайдуков, 1993. С. 50). К 1474-1479 гг. относятся два пула с названием города $(\Gamma-83,159)$. К заключительному этапу чеканки Михаила Борисовича 1480-1485 гг. из состава коллекции принадлежит только одна медная монета с названием города (Г-268).

Время княжения в Твери Ивана Ивановича, продолжавшееся с 1485 по 1490 г., отразилось среди находок тремя пулами $\left(\Gamma-308,343,306-327^{12}\right)$. Правление Василия Ивановича, длившееся только год, представлено одной медной монетой ${ }^{13}$ (Г-349).

При анализе серии больших пул обращает на себя внимание преобладание экземпляров, выпущенных во второй половине XV в. При этом чеканка подобных монет, например в Москве, происходила в XV в. В Твери «денежный двор» начал работать в период княжения Ивана Михайловича около 1413 г., а при великом князе Тверском Борисе Александровиче (с 1426 по 1462 г.) осуществляется уже регулярная и массовая эмиссия как медных, так и серебряных денежных знаков (Гайдуков, 1993. С. 45, 46; Сотникова, 1997. С. 65,$66 ; 1998$. С. 130).

Почти полное отсутствие в коллекции монет первой половины XV в. может указывать на особенности формирования культурного слоя в пределах исследуемого участка в это время, т. е. его неинтенсивное использование.

Причина количественного преобладания пул Михаила Борисовича может являться следствием его долгого правления и высокой интенсивности денежных выпусков в Твери в 1461-1485 гг., но более вероятно, что во второй половине XV в. на Ржевском городище происходят более активные жизненные процессы, нежели в предыдущее время. На это указывает и наличие экземпляров, чеканенных Иваном Ивановичем в период его пятилетнего тверского княжения, и даже монеты Василия Ивановича, занимавшего Тверской стол около года.

\footnotetext{
12 Точное определение монеты невозможно ввиду ее плохой сохранности.

13 Также в коллекции присутствует обломок большого пула, который не удалось атрибутировать.
} 
Следует отметить, что большие пула относительно ровно покрывают все хронологические этапы, выделенные для них П.Г. Гайдуковым, что может указывать на их планомерное выпадение в культурный слой на протяжении второй половины XV в. Из обращения медные монеты по причине своей низкой покупательной стоимости могли выходить относительно быстро, например, в виде обычных потерь. К средствам расчета из благородных металлов у населения было более бережливое отношение ${ }^{14}$.

Показательную картину в этом вопросе дает материал единичных монетных находок или их скоплений, происходящих из культурного слоя городищ и селищ, которые, по сравнению с кладами, дают более точный состав и динамику развития денежного обращения в прошлом (Волков, 2003. С. 35).

Так, при раскопках на территории Романова двора в Москве было зафиксировано 127 пул, из которых к большим (конец XIV в. - первая половина XV в.) принадлежали только пять экземпляров, а к малым (90-е гг. XV в. - середина XVI в.) - 122. Лишь одно из найденных больших пул с четвероногим животным относилось к древнему слою XIV - первой половине XVI в. Остальные монеты в древности были перемещены в более поздние слои (Гайдуков, Кренке, 2009. С. 103, 104).

Еще один монетный комплекс, найденный в Москве в ходе раскопок нижних ярусов мостовой, шедшей поверх плотины от Неглименского моста к Воскресенским воротам Китай-города, показывает, что уже к концу 1530 -х - началу 1540 -х гг. русское денежное обращение полностью очистилось от многообразных монет, чеканенных в XV - первой трети XVI в., и их кустарных подражаний (Зайцев, 2018. С. 180). Материалы немногочисленных кладов, содержащих пулы, также указывают на быстрый выход из обращения экземпляров, чеканенных в XV в., и их быструю замену поздними малоформатными аналогами (Гайдуков, 1993. С. 70; Хухарев, 2004. С. 149, 150).

Таким образом, группа больших пул, зафиксированных на Ржевском городище, может рассматриваться в качестве надежного хронологического индикатора, маркирующего культурный слой второй половины XV в.

${ }^{14}$ Показательно соотношение количества находок серебряных копеек и пул, полученных при археологических раскопках Романова двора, когда в горизонте 2 на две с копейки Ивана IV пришлось 86 пул, т. е. 1 : 43 (Гайдуков, Кренке, 2009. С. 103, 104).
В середине 30-х гг. XVI в. в Москве происходит уменьшение весовой нормы серебряной деньги, сопровождающееся и снижением веса пул, причем не в той же пропорции, а сразу в три раза, что позволило увеличить рентабельность медного чекана для казны (Зайцев, 2018. С. 179). В составе рассматриваемой коллекции присутствуют 15 маленьких пул, выпущенных в Твери, Москве, Пскове и Новгороде (табл. 1). Среди них преобладают тверские экземпляры, несущие изображение птицы влево с цветком в клюве (Г-358), чеканка которых происходила с 1490-х гг. ${ }^{15}$ (Зайцев, $2006 б$. С. 25). Прекращение эмиссии медных монет в Твери В. В. Хухарев связывает с разгромом княжества опричным походом Ивана IV в 1569-1570 гг. (Хухарев, 2000. C. 146).

К продукции московского денежного двора принадлежат пула с изображением крылатой сирены на лицевой стороне, выпуск которых начался в период проведения денежной реформы Елены Глинской в 1535-1538 гг. и продолжался как минимум до начала 60-х гг. XVI в. (Зайцев, 2018. С. 181). Не позднее конца 1480-х гг. монеты этого типа начинают чеканить в Новгороде, а после 1510 г. в Пскове (Зайцев, 2006б. С. 25, 67).

Пула, имевшие низкую реальную стоимость, были в значительной степени востребованы в «мелочной» торговле, в связи с чем на протяжении XVI в. выпускались значительными тиражами, освобождая большое количество серебра для крупных финансовых операций (Гайдуков, 1993. С. 74-76; Зайцев, 2004. С. 78, 79; 2018. С. 181). По подсчетам П. Г. Гайдукова, после денежной реформы 1530-х гг. число пул в копейке составляло 60 или 70. К концу XVI в. это соотношение изменяется до $1: 120$ (Гайдуков, 1993. С. 76).

О месте медной монеты в русской денежной системе есть сведения в записках путешественников и дипломатов. Так, Д. Гесси под 1554 г. указывал: «Однако есть там медные монеты, служащие для облегчения московских бедняков и только для покупки кваса, воды и фруктов, например орехов, яблок и т. п.» (Гайдуков, 1993. С. 74).

Присутствие пул на многочисленных селищах и мелких городищах позволяет изменить господствующее до недавнего времени мнение о них как о чисто городской монете. Их массовая чеканка в конце XIV - первой половине XV в. и ак-

\footnotetext{
${ }^{15}$ При раскопках в Москве на Манежной площади такие монеты зафиксированы в культурном слое, сформированном до пожара 1493 г. (Зайцев, 1995. С. 47, 48).
} 
тивное участие в денежном обращении на обширной территории русского государства могут свидетельствовать о высокой степени развития товарно-денежных отношений (Зайцев, 2004. С. 78, 79).

Результаты археологических раскопок в Москве, Твери и других городах показывают, что в обращении маленькие пула сохранялись вплоть до конца XVI в. В культурном слое XVII в. они полностью отсутствуют по причине полного обесценивания в результате продовольственного кризиса и голода 1602-1603 гг. ${ }^{16}$ (Гайдуков, 1993. С. 73; Зайцев, 2018. C. 181,182$)$.

Таким образом, полученная на Ржевском городище коллекция малых пул является хронологическим индикатором культурного слоя конца XV-XVI вв. Преобладание в ней продукции тверского денежного двора объясняется тем, что медные монеты, в отличие от серебряных, гораздо реже уходили от своих эмиссионных центров (Зайцев, 2009. С. 33). При этом на русской территории вплоть до начала XVI в. существовали устойчивые локальные зоны денежного обращения, границы которых в целом соответствовали политическим рубежам новгородских и псковских земель, с одной стороны, и «низовских» княжеств, с другой. Во второй половине правления Ивана III экономические зоны между регионами практически стираются и постепенно складывается общерусская денежная система (Волков, 2001. С. 133; 2012. C. 173).

В составе коллекции времени обращения маленьким пулам синхронны три серебряные деньги и две копейки Ивана IV, отчеканенные в «княжеский» и «царский» периоды его правления в Москве, Новгороде и Пскове (табл. 1). Такие монеты выпускались огромными тиражами, что обеспечило их доминирование на русском денежном рынке вплоть до начала второго десятилетия XVII в. Это убедительно иллюстрируют материалы кладов Смутного времени, в которых монеты Ивана Васильевича количественно преобладают над эмиссиями других правителей (Мельникова, 2003).

К денежным знакам, выпущенным на основании стопы в три рубля из гривенки серебра, принадлежат и четыре новгородские копейки Бориса Годунова (табл. 1). В период его царствования проводилась интенсивная монетная чеканка, при этом наиболее массовая продукция выпускалась на Московском денежном дворе (Мельникова, 2005. С. 38). Ввиду этого кажется необычным отсутствие среди ржевских на-

${ }^{16}$ Цены на хлеб в центральных районах страны к 1603 г. выросли более чем в 20 раз (Зайцев, 2018. С. 181, 182). ходок столичных копеек. Вероятно, причина этого связана с событиями периода Смутного времени, когда русской денежной системе вновь стал присущ региональный характер (Векслер, Мельникова, 1999. C. 85). Также обращает на себя внимание отсутствие в коллекции монет Лжедмитрия I и Василия Шуйского, которые в значительном количестве встречаются в культурном слое начала XVII в.

В 1613 г. правительство Михаила Федоровича проводит денежную реформу, итогом которой стало повышение монетной стопы до четырех рублей из гривенки серебра. На начальном этапе реорганизации основной сырьевой базой для новых денег служили старые «тяжелые» монеты, выкупаемые правительством у населения с «наддачей». В 1620 г. из Пскова сообщали, что все «деньги старые переделаны до 128-го году» (Зверев, 2005. С. 232, 240).

Таким образом, рубежом массового обращения денежных знаков трехрублевой стопы можно считать второе десятилетие XVII в. Но следует учитывать, что единичные «тяжелые» монеты оставались в обращении на протяжении всего XVII в. и известны в кладах петровского времени (Быков, 2001. С. 208).

Эмиссия Михаила Федоровича в составе коллекции представлена семью копейками, чеканенными на Московском денежном дворе. Долгое правление первого царя династии Романовых, а также необходимость в больших денежных суммах для налаживания расстроенной экономики и военные расходы привели к тому, что даже в кладах второй половины XVII в. монеты 1613-1645 гг. занимают значительное место. Копейки Михаила Федоровича являются младшими проволочными монетами, обнаруженными в ходе работ на Ржевском городище. Отсутствие денежных знаков Алексея Михайловича, битых как из серебра, так и меди ${ }^{17}$, а также выпусков его приемников на престоле, скорее всего, указывает на замирание жизни на Соборной Горе во второй половине XVII в.

Следующая серия монет связана уже с имперской историей России и отражена серией мелких номиналов, чеканенных из меди в XVIII-XIX вв. Младшими в составе коллекции являются 5 рейхспфеннигов 1940-1944 гг. и советская копейка 1940 г.

Помимо монет, в ходе надзора была найдена половина актовой печати Плотницкого конца Ве-

\footnotetext{
${ }^{17}$ C 1655 по 1662 гг. чеканка медных монет в России носила массовый характер, а процессы инфляции, приведшие к практическому обесцениванию таких денежных знаков, явились причиной их частой потери.
} 
ликого Новгорода. Одна из аналогичных булл сохранилась при грамоте 1450 г. Еще две актовые печати первой половины XIV в., принадлежащие новоторжским наместникам, были зарегистрированы у местных жителей (рис. 15) (Янин, 1970. C. $61-66$; C. 135,230$)$.

Немногочисленный нумизматический материал середины XIV в. и рубежа XIV-XV вв., а также две вислые печати новоторжских наместников маркируют историю города, когда он, занимая стратегическое положение на границе Литовского, Московского и Тверского княжеств, став объектом борьбы между ними, неоднократно переходил из рук в руки. Вероятно, эти многочисленные переходы, не способствующие развитию товарно-денежных отношений, и явились причиной немногочисленности найденного нумизматического материала второй половины XIV первой половины XV в. (рис. 16).

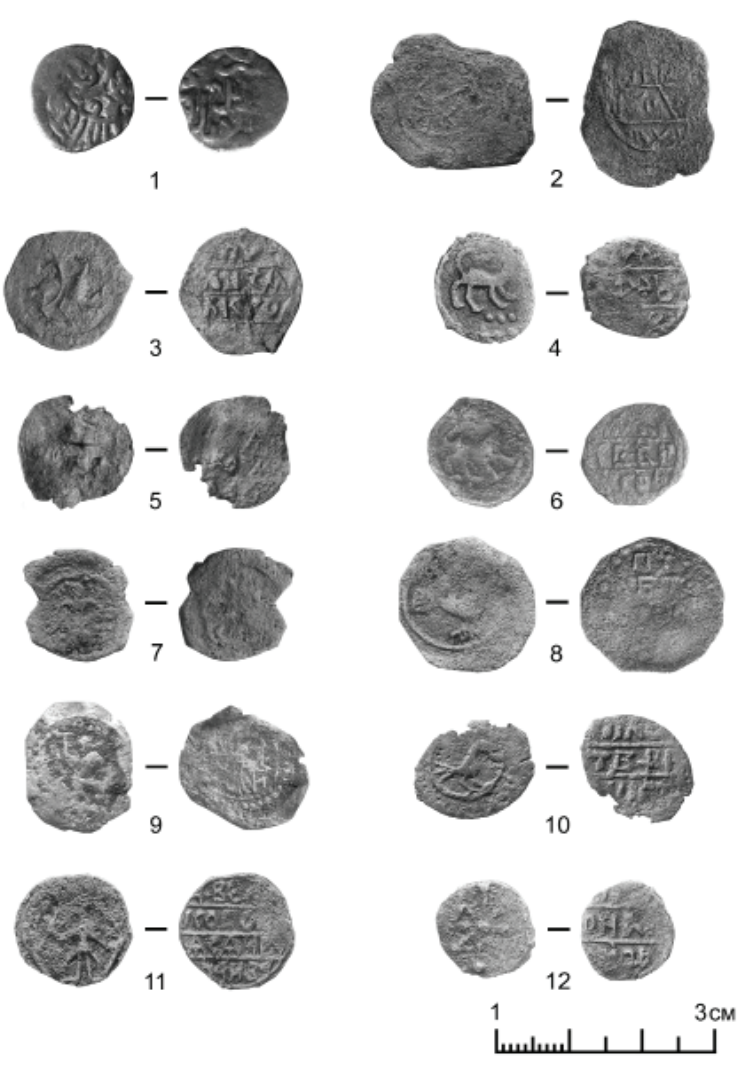

Рис. 15. Нумизматический материал, зарегистрированный в 2019 г. на Ржевском городище Соборная гора: 1 - анонимный пул 743 г. $x$. (1342 р. х.), Сарай ал-Джедид; 2 - пуло 1425-1461 ге. князя Бориса Александровича, Городен; 3-10 - пуль 1461-1485 г2. князя Михаила Борисовича, Тверь; 11 - пуло 1485-1490 гг. князя Ивана Ивановича, Тверь; 12 - пуло 1490-1491 г2. князя Василия Ивановича, Тверь
Изменившаяся ситуация во второй половине XV в. отразилась в коллекции серией тверских пул, скорее всего, равномерно выпадавших в культурный слой на протяжении княжений в Твери Михаила Борисовича, Ивана Ивановича и Василия Ивановича. Отсутствие в коллекции серебряных монет, активно выпускающихся в русских княжествах в это время, указывает на особенности экономического развития города, в котором, скорее всего, преобладала мелкая розничная торговля.

Следующий XVI в. в составе коллекции представлен маленькими медными пулами и серебряными монетами Ивана IV «княжеского» и «царского» периодов правления. Появление монет с высокой покупательной стоимостью может указывать на экономическое развитие города в это время. В пользу этого говорит также и присутствие в коллекции серебряных копеек Бориса Годунова.

В период Смутного времени Ржев становится участником бурных событий. Город захватывается отрядом Ивана Болотникова, присягает на верность Лжедмитрию II и Василию Шуйскому, завоевывается войсками Сигизмунда III, однако эти исторические эпизоды в составе нумизматической коллекции отражения не нашли. Период после Смутного времени маркируется серией московских копеек Михаила Федоровича, чеканенных как в начале, так и конце его правления. До 1650-х гг. Ржев сохраняет важное военно-стратегическое значение на московско-литовском пограничье, имеет крупный гарнизон войск. Однако после прекращения войны с Польшей город потерял свое военное значение, что, вероятно, является причиной отсутствия среди находок монет Алексея Михайловича, в том числе и медных копеек, чеканенных огромными тиражами.

Следующая серия монет относится уже к имперскому периоду России, когда на ржевском городище 1754 г. возводится каменный собор.

Таким образом, полученный в ходе исследования Ржевского городища нумизматический и сфрагистический материал имеет статус высокоинформативного археологического источника, позволяющего выделить хронологические этапы, отражающие различную интенсивность жизни, особенности экономического развития и направления деловых связей города.

Наблюдения за строительными работами вокруг обелиска в 2019 г. впервые позволили археологам исследовать исторический центр города Ржева (городище Соборная Гора), который до сих пор был закрыт для научного изучения. Археологические наблюдения предоставили уникальную возможность 


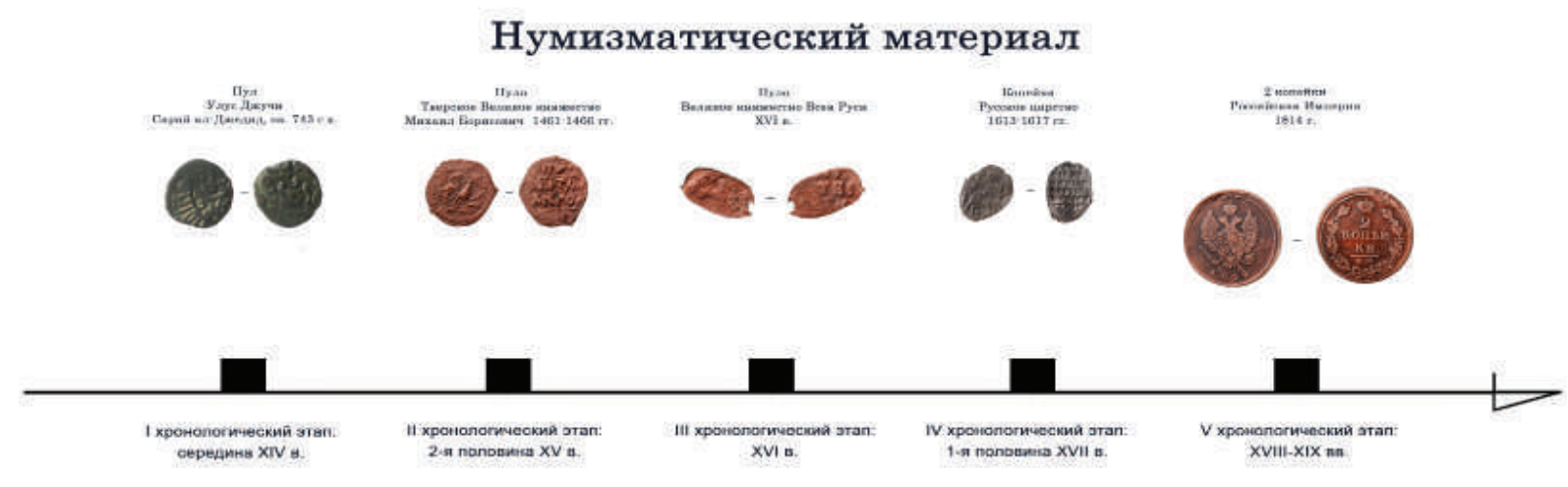

Рис. 16. Ржев. Городище Соборная Гора. Схема денежного обращения на памятнике

подробно проследить стратиграфию памятника и собрать представительную коллекцию находок, что может помочь уточнить датировку и планиграфию городища. В ходе наблюдений было установлено, что в разных частях объекта археологического наследия стратиграфия верхней части культурных напластований имеет различную структуру. В западной, возвышенной части городища вся верхняя часть толщи культурных напластований, вскрытой строительными траншеями, занята слоями и прослойками битого кирпича, извести, колотого бутового камня и строительного раствора, которые связаны со строительством и разрушением Успенского собора. В связи с полученными данными слои, затронутые строительными работами в западной части памятника, могут быть отнесены к XVII-XX вв. По-видимому, современные траншеи и перекопы 1941-1943 гг. не смогли достигнуть слоя средневекового городища, который еще дождется своих исследователей.

Помимо многочисленных перекопов со строительным мусором, которые остались после разрушения храма в 1957 г. и выравнивания территории под строительство обелиска, на западной площадке была выявлена поверхность фундамента южной стены Успенского собора, остатки апсид и алтарной части храма. Был выявлен цоколь собора и фрагмент подземной крипты в районе алтарной части, где могут сохраняться наиболее престижные погребения или даже остатки захоронений ржевских святых Владимира и Агриппины. Эти находки позволили точно локализовать границы каменного собора и колокольни 1764 г. и 1830 г. В свою очередь, эта информация сможет помочь уточнить охранную документацию объекта культурного наследия и упростит поиски этого памятника будущим исследователям. На верхней площадке было обнаружено несколько монет XVIII-XIX вв. и обломок сабли, который предположительно может быть датирован XVII в. Строительный мусор и перепланировки XX в. полностью перекрыли ранний слой памятника, но на вероятное присутствие таких слоев указывает находка древнерусского перефелитового пряслица.

К западу от фундаментов собора и на южной границе обелиска были обнаружены остатки фрагментов еще двух каменных фундаментов, которые располагались за пределами собора и его пристроек XIX в. Они, скорее всего, относятся к наиболее ранним каменным строениям на территории крепости. Можно предположить, что они могут быть связаны с первым каменным храмом на городище или другими постройками в крепости. Предварительно эти части фундаментов могут быть отнесены к XVI-XVII вв. Также на западном краю площадки городища обнаружен фрагмент первоначальной засыпки деревянных стен - «тарасов» крепости XVII в.

В восточной, пониженной части городищенского мыса культурные напластования были сложены из темно-серого гумусированного слоя, который был нарушен многочисленными перекопами. Судя по письменным источникам, в XVII - первой половине XX в. восточная часть городища была всегда плотно застроена «осадными» дворами и дворами церковного причта. При исследовании этой части памятника удалось локализовать лишь остатки фундаментов деревянных домов XIX - первой половины $\mathrm{XX}$ в. Вдоль восточного края городища были зафиксированы прослойки обожженного краснокоричневого суглинка, который может быть связан с засыпкой крепостных стен середины XVII в. Именно вдоль восточного и северо-восточного края площадки городища сделаны основные находки средневековых монет (пул и чешуек) и предметов вооружения XVII в. Большая часть находок относится к Смутному времени и раннему 
этапу московского присутствия в Ржеве. Можно предположить, что часть монет, предметы вооружения и следы пожара связаны с штурмом ржевской крепости отрядом Александра Лисовского в 1615 г. Среди наиболее ранних предметов на нижней площадке следует отметить обломок древнерусской свинцовой печати, которая датируется XIV - началом XV в. Также в нижней части культурных напластований были обнаружены кремневые отщепы и сколы, относящиеся к эпохе неолита, и часть каменного топора Фатьяновской культуры эпохи бронзы.

Таким образом, городище Соборная Гора в Ржеве оказалось, несмотря на многочисленные нарушения культурного слоя, многослойным памятником археологии, на котором присутствуют материалы различных эпох: стоянки эпохи мезолита, памятника эпохи бронзы, древнерусского города XIII-XV вв., крепости эпохи Московского царства XVI-XVII вв. и слой, связанный со строительством и существованием Успенского собора и церковного причта XVII-XX вв. Эти находки чрезвычайно важны для реконструкции истории Ржева и этапов его заселения.

\section{Источники и литература}

Алексеев Л. В. 1972. Отчет о раскопках, проведенных летом 1972 г. Днепро-Двинским отрядом Прибалтийской экспедиции АН СССР // Архив ИА PAH. Р-1. № 5471.

Алексеев Л. В., 1980. Смоленская земля в IXXIII вB. M.

Беляев Л. А., 2019. Алексеевский и Зачатьевский: два монастыря Москвы в зеркале археологии и истории XIV-XVI веков // Исторические Записки. 2019. № 18 (136).

Беляев Л. А., Гайдуков П. Г., 2006. Средневековые монеты из раскопок в Зачатьевском монастыре в 2005 г. // Проблемы спасательной археологии. Научно-практическая конференция к 75-летию со дня рождения А.Г. Векслера (Москва, 28-29 сентября 2006 г.). М.

Быков А. В., 2001. Архангельский клад начала XVIII в. // Десятая Всероссийская нумизматическая конференция: Тезисы докладов (Псков, 15-20 апреля 2002 г.). М.

Векслер А. Г., Мельникова А. С. 1999. Российская история в московских кладах. М.
Волков И. В., 2001. Некоторые итоги составления сводки кладов русских серебряных монет конца XIV - первой трети XVI в. // Девятая Всероссийская нумизматическая конференция: Тезисы докладов (Великий Новгород, 16-21 апреля 2001 г.). СПб.

Волков И. В., 2003. Средневековые монеты с селища Могутово-2 // Древняя Русь: вопросы медиевистики. М. № 2 (12).

Волков И. В. 2004. Особенности денежного обращения на рязанско-московском пограничье в последней четверти XIV - начале XV века // Археология Подмосковья: Материалы научного семинара. M.

Волков И. В., 2012. Новый клад монет конца $\mathrm{XV}$ в. из Рязанской области // CHВЕ. Вып. 4.

Воротникова И. А., Неделин В. М., 2013. Кремли, крепости и укрепленные монастыри Русского государства XV-XVII веков. Крепости Центральной России. М.

Гайдуков П. Г. 1993. Медные русские монеты конца XIV-XVI веков. М.

Гайдуков П. Г., Кренке Н. А., 2009. Средневековые монеты из раскопок на Романовом дворе. Археология Романова двора: предыстория и история центра Москвы в XII-XIX веках. М.

Гомзин А. А., 2011. Заметки по хронологии и топографии монетных находок XIV-XVIII вв. из Переяславля Рязанского // Материалы по археологии Переяславля Рязанского. Рязань. Вып. 1.

Гомзин А. А. 2015. Монетные находки XIVXVI вв. в кремле Переяславля Рязанского (сезоны 2009-2013 гг.) // Нумизматические чтения ГИМ 2015 года: Материалы докладов и сообщений (Москва, 30 ноября - 1 декабря 2015 г.). М.

Зайцев В. В., 1995. Новые находки медных пул XVXVI вв. при археологических раскопках в Москве // Третья Всероссийская нумизматическая конференция: Тезисы докладов (Владимир, 17-21 апреля 1995 г.). М.

Зайцев В. В. 1999. Три монетных комплекса XV-XVI вв. из раскопок на Гостином дворе в Москве // Седьмая Всероссийская нумизматическая конференция: Тезисы докладов и сообщений (Ярославль, 19-23 апреля 1999 г.). М.

Зайцев В. В., 2004. Русские монеты. Средневековое поселение Настино. Труды Подмосковной археологической экспедиции ИА РАН. М. Т. 2. 
Зайцев В. В., 2006а. Находки «иногородних» медных монет XIV-XV вв. в Москве // Проблемы спасательной археологии. Научно-практическая конференция к 75 -летию со дня рождения А. Г. Векслера (Москва, 28-29 сентября 2006 г.). М.

Зайцев В. В. 2006б. Русские монеты времени Ивана III и Василия III. Киев.

Зайцев В. В., 2009. Редкие и неизданные медные русские монеты XIV-XV вв. // CHBE. Вып. 3.

Зайцев В. В., 2018. Денга Бориса Годунова и некоторые вопросы участия мелких номиналов в обращении в начале XVII в. // Нумизматические чтения ГИМ 2018 года: Материалы докладов и сообщений (Москва, 27, 28 ноября 2018 г.). М.

Зверев С. В., 2005. К истории монетного производства в русском государстве в XVI-XVII вв. // НЭ. Вып. XVII.

Зорин А. В., 2009. Великий рейд Александра Лисовского (март-декабрь 1615 г.) // Русский сборник. Брянск. Вып. 5.

Иванов Ф. И., 1958. Текст отчета о произведенных обследованиях и раскопках археологических памятников в районе г. Ржева и Калинина в 1958 году // Архив ИА РАН. Р-1. № 1682.

Исланова И. В., 2010. Отчет об инвентаризации археологических памятников в г. Ржеве в 2010 г. // Архив ИА РАН. Р-1. № 39799.

Исланова И. В., Оруджев Р. А., 2017. Укрепленные поселения на территории современного города Ржева (археологические материалы) // Древняя Русь: вопросы медиевистики. 2017. № 1 (67).

Козлова О. А., 2017. Мероприятия по сохранению объекта археологического наследия «Городище Ржев» на участке реставрации Обелиска в г. Ржев. ООО «ТНИИР-ЦЕНТР». Тверь.

Квашнин-Самарин Н. Д., 1887. Исследование об истории княжеств Ржевского и Фоминского. Тверь.

Кучкин В. А., 1984. К изучению процесса централизации в восточной Европе (Ржева и ее волости в XIV-XVвв.) // История СССР. № 6.

Мельникова А. С., 2003. Русские монетные клады рубежа XVI-XVII веков. Киев.

Мельникова А. С., 2005. Очерки по истории русского денежного обращения XVI-XVII веков. М.
Нефёдов В. С., 2007. Археологическая карта России. Тверская область. М. Ч. 2.

Описание церкви во имя Успения Божьей Матери. г. Ржев // РО НА ИИМК РАН. Ф. Р-3. Д. 6659.

Оруджев Р. А., 2004. Отчет о разведочных работах на территории современного г. Ржева в Тверской области. 2004 г. // Архив ИА РАН. Р-1.

Оруджев Р. А., 2005. Отчет о разведочных работах на территории современного г. Ржева в Тверской области. 2005 г. // Архив ИА РАН. Р-1.

Петров П. Н., 1997. Находки джучидских монет на территории Нижегородской области // Древности нижнего Поволжья. Нижний Новгород. Вып. 2. Нумизматический сборник. Т. I.

Плетнев В. А., 1903. Об остатках древности и старины в Тверской губернии. К археологической карте губернии. Тверь.

Полное собрание русских летописей. Т. 14. СПб., 1965.

Полное собрание русских летописей. Т. 34 . СПб., 1978.

Рикман Э. А., 1951. Обследование городов Тверского княжества // КСИИМК, Вып. XLI.

Салимов А. М., 2015. Средневековое зодчество Твери и прилежащих земель. XII-XVI века. Тверь. T. II.

Симсон П. Ф., 1903. Каменный век под г. Ржевом. Тверь.

Симсон П. Ф., 1916. Из истории Ржева. Тверь.

Сотникова М. П., 1997. О денежном чекане великого князя Тверского Ивана Михайловича (первая четверть XV в.) // Пятая Всероссийская нумизматическая конференция: Тезисы докладов и сообщений (Москва, 21-25 апреля 1997 г.). М.

Сотникова М. П., 1998. О денежном чекане великого князя Тверского Бориса Александровича (1425-1461) // Шестая Всероссийская нумизматическая конференция: Тезисы докладов и сообщений (Санкт-Петербург, 20-25 апреля 1998 г.). М.

Хухарев В. В., 2000. Тверской денежный двор в XVI в. при Иване Грозном // Восьмая Всероссийская нумизматическая конференция: Тезисы докладов и сообщений (Москва, 17-21 апреля 2000 г.). М. 
Хухарев В. В., 2004. О новой находке клада малых пул и подражаний на Старицком городище // Двенадцатая Всероссийская нумизматическая конференция: Тезисы докладов и сообщений (Москва, 19-24 апреля 2004 г.). М., 2004.

Янин В. Л., 1970. Актовые печати древней Руси $\mathrm{X}-\mathrm{XV}$ вв. M. T. II. 